\title{
Przeciwwirusowe związki izolowane z roślin
}

\section{prof. UAM dr hab. Robert Nawrot $^{1 凶,}$}

dr Alicja Warowicka², mgr Oskar Musidlak dr Martyna Węglewska ${ }^{1}$, mgr Sophia Bałdysz ${ }^{1}$,

\section{prof. dr hab. Anna Goździcka- -Józefiak ${ }^{1}$}

${ }^{1}$ Pracownia Wirusologii Molekularnej, Wydział Biologii, Uniwersytet im. Adama Mickiewicza w Poznaniu

'Zakład Fizjologii i Biologii Rozwoju Zwierząt, Wydział Biologii, Uniwersytet im. Adama Mickiewicza w Poznaniu

https://doi.org/10.18388/pb.2019

$\bigotimes_{\text {autor korespondujący: rnawrot@amu.edu.pl }}$

Słowa kluczowe: roślinne związki przeciwwirusowe, właściwości immunomodulujace związków roślinnych

Wykaz skrótów: BBR (ang. berberine) - berberyna; BoHV-1 (ang. Bovine herpesvirus type 1) - herpeswirus bydła typu 1; GRP (ang. glycine-rich RNA-binding proteins) - białka bogate w glicynę wiążące RNA; EGCG (ang. epigallocatechin-3-gallate) - galusan epigallokatechiny; EMCV (ang. Encephalomyocarditis virus) - wirus zapalenia mózgu i mięśnia sercowego; EV71 (ang. Enterovirus 71) - ludzki enterowirus 71; RIPs (ang. ribosome-inactivating proteins) - białka inaktywujące rybosomy; EBV (ang. Epstein-Barr virus) - wirus Epsteina-Barr; HBV (ang. Hepatitis B virus) - wirus zapalenia wątroby typu B; HCV (ang. Hepatitis C virus) - wirus zapalenia wątroby typu C; HCMV(ang. Human cytomegalovirus) - ludzki wirus cytomegalii; HIV (ang. Human immunodeficiency virus) ludzki wirus niedoboru odporności; HPV (ang. Human papillomavirus) - ludzki wirus brodawczaka; HSV (ang. Herpes simplex virus) - wirus opryszczki pospolitej; PR (ang. pathogenesis-related proteins) - białka związane z patogenezą; RSV (ang. Respiratory syncytial virus) - syncytialny wirus oddechowy; IAV (ang. Influenza A virus) - wirus grypy typu A; PRV (ang. Pseudorabies virus) - wirus pseudowścieklizny; NDV (ang. Newcastle disease virus) - wirus choroby Newcastle; PHT (ang. phenylheptatriyne);

\section{STRESZCZENIE}

Wirusy są wewnątrzkomórkowymi patogenami, które wykorzystują liczne procesy komórkowe oraz białka i czynniki wirusowe do swojej replikacji. Obecnie nie ma odpowiednich środków umożliwiających zwalczanie licznych zakażeń wirusowych. Skuteczny lek przeciwwirusowy nie powinien uszkadzać komórkowych procesów metabolicznych w zakażonej komórce, jak również w komórkach niezainfekowanych. Rośliny stanowią potencjalne źródło czynników przeciwwirusowych, takich jak: alkaloidy, flawonoidy, kwasy fenolowe, fenylopropanoidy, ligniny, terpenoidy, chininy, taniny, tiofeny, poliacetyleny czy białka. Niektóre z tych czynników wykazują szerokie spektrum aktywności przeciwwirusowej.

\section{WSTĘP}

Zakażenia wirusowe są jedną z głównych przyczyn chorób i śmiertelności ludzi na świecie. Sprzyjają temu takie czynniki, jak mobilność, wzrost urbanizacji, zabiegi kliniczne, a przede wszystkim brak odpowiednich leków przeciwwirusowych. Obecnie dostępnych jest 19 różnych czynników przeciwwirusowych, które stosowane są do leczenia zakażeń takimi wirusami, jak HIV (ang. Human immunodeficiency virus), wirus opryszczki pospolitej, wirusy grypy i zapalenia wątroby [1,2]. Dla większości wirusów atakujących ludzi brakuje odpowiednich leków, jak również niedostępne są szczepionki. Źródłem nowych czynników przeciwwirusowych mogą być rośliny, z których ekstrakty od dawna były stosowane w medycynie ludowej do leczenia licznych zakażeń. Szacuje się, że 20$30 \%$ roślin tropikalnych i z regionów o klimacie umiarkowanym może zawierać czynniki o aktywności przeciwwirusowej. Liczne związki przeciwwirusowe izolowane dotychczas z roślin mają różną strukturę chemiczną, jak również odmienny jest mechanizm ich działania molekularnego (Tabela 1) [2,3]. Związki takie wyizolowano z roślin zaliczanych do różnych rodzin. Niektóre substancje roślinne wykazują aktywność przeciwwirusową względem kilku wirusów, jak np. glicyryzyna (ang. glycyrrhizin) izolowana z lukrecji gładkiej (Glycyrrhiza glabra) względem wirusa herpes HSV (ang. Herpes simplex virus), grypy (ang. Influenza virus), czy SARS (ang. severe acute respiratory syndrome) [4,5]. Szczególnie interesujące są wytwarzane przez rośliny metabolity wtórne, takie jak polifenole, terpeny, alkaloidy, których aktywność farmakologiczna jest od dawna znana i wykorzystywana $w$ medycynie.

Leki przeciwwirusowe muszą cechować się określonymi właściwościami, co wynika z natury wirusów. Wirusy są wewnątrzkomórkowymi pasożytami, których namnażanie się w komórce jest zależne od czynników i procesów komórkowych, jak również czynników wirusowych. Z tego względu skuteczny lek przeciwwirusowy musi swoiście blokować namnażanie się wirusów i nie uszkadzać komórki, jak też komórek sąsiednich (Ryc. 1) [6]. Celem działania leków przeciwwirusowych mogą być wirusowe cząsteczki - zlokalizowane na powierzchni wirionu, rozpoznające komórkę i ułatwiające wirusowi adsorpcję oraz penetrację do jej wnętrza - wirusowe kwasy nukleinowe, białka, czy wirusowe osłonki pochodzące $\mathrm{z}$ błon komórkowych gospodarza. Wirusy zawierające osłonki wykorzystują błony komórkowe do składania wirusowych cząstek wewnątrz komórki i ich uwalniania z komórki, dlatego ich zniszczenie uniemożliwia przebieg tych procesów. Innym celem leków przeciwwirusowych mogą być wirusowe kwasy nukleinowe. Materiałem genetycznym wirusów może SARS-CoV-2 (ang. Severe acute respiratory syndrome coronavirus 2) - wirus ciężkiej niewydolności odechowej typu 2; SeV (ang. Sendai virus) - wirus Sendaj; SINV (ang. Sindbis virus) - wirus Sindbis; VSV (ang. Vesicular stomatitis virus) - wirusa pęcherzykowego zapalenia jamy ustnej;

Finansowanie: Praca została sfinansowana z konkursu pt. „Badania nad COVID-19” ze środków Uniwersytetu im. Adama Mickiewicza w Poznaniu (pkt. 17, podpkt. 2) oraz grantów NCN PRELUDIUM nr 2016/21/N/NZ6/00997 (O. Musidlak) i NCN OPUS nr 2019/35/B/ NZ9/03851 (R. Nawrot). 
Tabela 1. Związki chemiczne o aktywności przeciwwirusowej izolowane z roślin.

\section{Roślinny czynnik przeciwwirusowy}

Alkaloidy i ich pochodne

Kumaryny

Flawonoidy

Terpenoidy (mono-, di-, tri-, seskwi-)

Fenole

Fenylopropanoidy

Taniny

Tiofeny i poliacetyleny

Chinony

Ligniny

Białka

\section{Przykłady roślin, z których wyizolowano}

pokrzyk wilcza jagoda (Atropa belladonna L.)

gumiak (Callphyllum lanigerum)

chryzantema wielokwiatowa (Chrysanthemum morifolium)

rozmaryn lekarski (Rosmarinus officinalis L.)

czapetka pachnąca (Syzygium aromaticum)

kawa arabska (Coffea arabica)

malina właściwa (Rubus idaeus L.)

czosnek właściwy (Allium satioum L.)

rabarbar dłoniasty (Rheum palmatum var. tanguticum)

twardnik japoński (Lentinus edodes)

papryka roczna (Capsicum annuum L.)

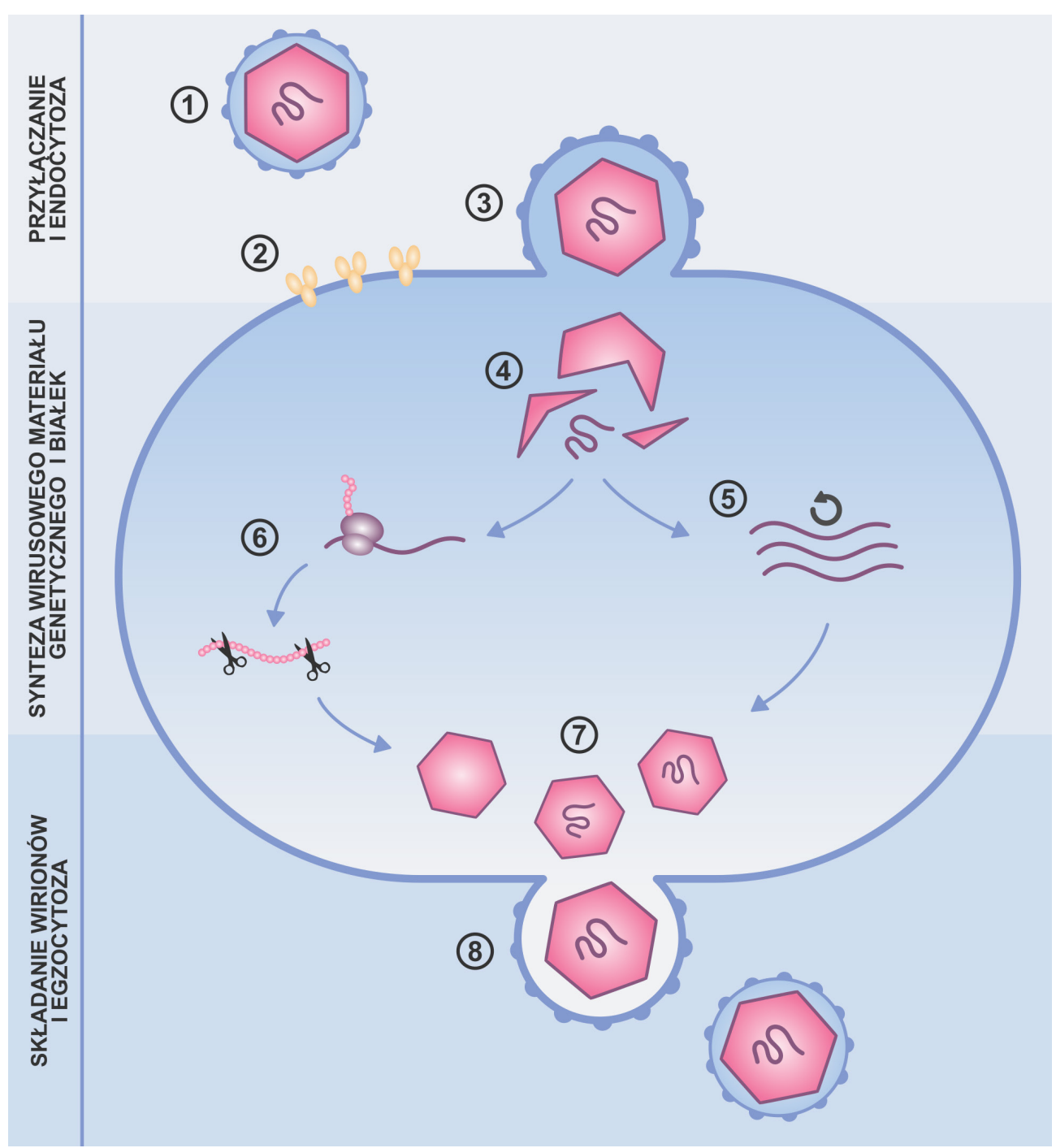

Rycina 1. Wpływ związków roślinnych na cykl replikacyjny wirusów.

Działanie przeciwwirusowe związków roślinnych może polegać na: wiązaniu się z cząsteczkami na powierzchni wirionu odpowiedzialnymi za rozpoznanie komórki przez wirusa i jego adsorpcję do komórki, blokowaniu receptorów na powierzchni komórki gospodarza, blokowaniu procesu fuzji błon i penetracji wirusa do komórki, hamowaniu odpłaszczania wirusowego materiału genetycznego, blokowaniu syntezy wirusowych kwasów nukleinowych, blokowaniu translacji wirusowych białek i ich obróbki potranslacyjnej, blokowaniu składania wirionów potomnych, blokowaniu uwalniania wirusowych cząstek potomnych z komórki. 
być DNA lub RNA. Synteza wirusowego DNA zachodzi z udziałem enzymów komórkowych lub wirusowych. W replikacji wirusowych genomów potomnych typu RNA biorą udział swoiste wirusowe replikazy RNA. Niektóre wirusy wymagają do replikacji wirusowej odwrotnej transkryptazy. Enzymy takie mogą stanowić doskonały cel dla terapii przeciwwirusowej. Większość dotychczas stosowanych leków jest inhibitorami tych enzymów. Badania nad lekami przeciwwirusowymi ukierunkowane są także na poszukiwanie czynników wzmacniających działanie układu odpornościowego [7].

\section{PRZECIWWIRUSOWE DZIAŁNIE ZWIĄZKÓW ROŚLINNYCH}

\section{ALKALOIDY}

Roślinne alkaloidy stanowią dużą (ponad 12 tysięcy związków), heterogenną grupę metabolitów wtórnych, charakteryzowaną przez obecność atomu azotu $\mathrm{w}$ jednej $\mathrm{z}$ pozycji w pierścieniu węglowym (Ryc. 2). Związki te zostały podzielone na ponad 20 grup ze względu na ich budowę chemiczną (pierścień heterocykliczny), szlak biosyntezy, czy biologiczne właściwości. Wyróżniamy m.in. alkaloidy tropanowe, indolowe, imidazolowe, purynowe, pirymidynowe [8].

Większość alkaloidów to związki aktywne biologicznie,

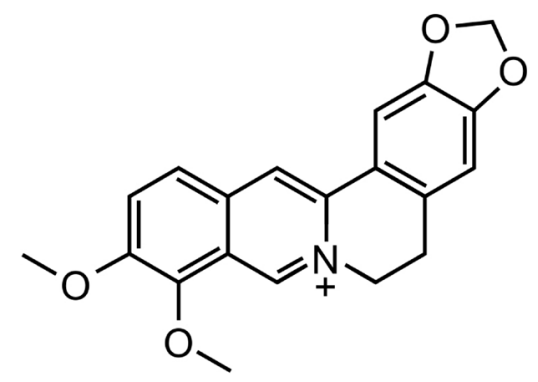

Rycina 2. Struktura chemiczna alkaloidu berberyny.

które od dawna były i nadal są powszechnie wykorzystywane w medycynie tradycyjnej, w leczeniu schorzeń układu pokarmowego, czy chorób zakaźnych [9]. Liczne badania wykazały, że mogą one działać przeciwbakteryjnie, przeciwnowotworowo, przeciwwirusowo i przeciwgrzybicznie. Naturalnie występujące alkaloidy, jak również ich syntetyczne pochodne stanowią obecnie bogate źródło do projektowania nowych, skutecznych leków [9].

Do tej pory poznano ponad 40 alkaloidów o właściwościach przeciwwirusowych. Związki te mogą znaleźć zastosowanie w leczeniu najbardziej popularnych i/lub zagrażających życiu zakażeń, np. wirusem polio, grypy, czy wirusem HIV [10]. Od wielu lat identyfikowane są liczne alkaloidy, które wykazują działanie przeciwko wirusowi HIV [11]. W grupie tej znajdują się związki, których mechanizm działania polega na blokowaniu replikacji wirusa w wyniku wiązania i/lub hamowania działania odwrotnej transktyptazy, m.in. korydyna znajdująca się w ekstrakcie liści krotona (Croton echinocarpus), aristolaktamy pochodzące $\mathrm{z}$ Dasymaschalon echinatum, emetyna z ipekakuany prawdzi- wej (Psychotria ipecacuanha), czy papaweryna z maku lekarskiego (Papaver somniferum) [11-14].

Alkaloidy mogą być także obiecującymi związkami w walce $\mathrm{z}$ wirusem grypy. Opisano ponad 43 alkaloidy, w tym te pochodzenia roślinnego, które mogą pomóc w zwalczaniu tego wirusa. Mechanizm ich działania polega na bezpośrednim wiązaniu białek wirusowych lub pośrednim działaniu w wyniku stymulacji układu immunologicznego gospodarza. Roślinne alkaloidy mogą blokować proces replikacji wirusa, hamować transport i dojrzewanie wirusowych białek (berberyna) lub jak alkaloidy chinolizydynowe, zaburzać transport do miejsca docelowego białek nukleokapsydu [15].

Wiele związków naturalnych, pochodzenia roślinnego wykazuje również działanie przeciwwirusowe względem wirusów HSV-1 i HSV-2. Znajdują się wśród nich takie alkaloidy, jak harman (ang. harmane), harmina (ang. harmine) oraz aptamina (ang. aptamine) [16,17]. Na przykład, harmina zaburza proces wnikania wirusa HSV do komórki i możliwość uwalniania jego cząstek potomnych, hamuje także aktywność komórkowych kinaz DYRK (ang. dual specificity tyrosine phosphorylation-regulated kinases) kluczowych dla replikacji wirusów HSV oraz HCMV (ang. Human cytomegalovirus) [18,19]. Innym przykładem może być aktywność alkaloidu tomatydyny (ang. tomatidine), pozyskiwanego $\mathrm{z}$ niedojrzałych, zielonych pomidorów. Związek ten wykazuje aktywność przeciwwirusową względem DENV (ang. Dengue virus) i ZIKV (ang. Zika virus) oraz alfawirusa z rodziny Togaviridae CHIKV (ang. Chikungunya virus), przenoszonych przez komary [20,21].

Jednym z naturalnych niskotoksycznych, roślinnych alkaloidów o silnych właściwościach przeciwwirusowych jest berberyna (BBR) [22]. Należy ona do alkaloidów izochinolinowych i jest głównym przedstawicielem klasy alkaloidów protoberberynowych. Aktywność przeciwwirusową BBR wykazano względem wirusa grypy H1N1 [23], wirusa Chikungunya oraz innych alfawirusów [24], enterowirusa 71 (EV71, ang. Enterovirus 71) [25], syncytialnego wirusa oddechowego (RSV, ang. Respiratory syncytial virus) [26], wirusa cytomegalii (CMV) [27], opryszczki (HSV) [28] oraz SARS-CoV-2 (ang. Severe acute respiratory syndrome coronavirus 2) [29]. BBR wykazuje również działanie przeciwbakteryjne, przeciwnowotworowe i przeciwzapalne [30]. Jego bogatym źródłem jest kilka roślin medycznych - berberys (Berberis vulgaris), cynowód chiński (Coptis chinensis), kłącze Coptis (Coptidis rhizome), gorzknik kanadyjski (Hydrastis canadensis), korkowiec amurski (Phellodendron amurense), czy glistnik jaskółcze ziele (Chelidonium majus). Aktywność przeciwwirusowa tego związku opiera się na działaniu na różne etapy cyklu replikacyjnego wirusów. Wykazano, że BBR blokuje replikację niektórych wirusów, w tym herpeswirusów (HSV, HCMV), HPV i HIV. Alkaloid ten wpływa również na szlaki komórkowe MEK-ERK, AMPK/mTOR oraz aktywność czynnika NF-kB, które odgrywają istotną rolę podczas wirusowej replikacji. Wykazano, że BBR obniża aktywność czynnika NF-kB w komórkach zainfekowanych oraz blokuje degradację inhibitora NF-kB (ІкBa) [31]. Może również wpływać na aktywność serynowo-treoninowych kinaz białkowych MAP, tzw. kinaz aktywowanych 
mitogenami (MAPK, ang. Mitogen activated protein kinases). Do aktywacji MAPK dochodzi podczas infekcji wirusowej, np. CHIKV. Wykazano, że BBR obniża aktywność MAPK w komórkach zainfekowanych CHIKV, zaburzając składanie wirusowej cząstki [32]. W komórkach zainfekowanych RSV oraz HBV (ang. Hepatitis B virus) obniża fosforylację kinaz p38 MAPK, wpływając na ich aktywność. BBR, poprzez blokowanie szlaku MAPK/ERK, hamuje również replikację wirusa grypy typu A (IAV, ang. Influenza A virus) - [33]. W komórkach zainfekowanych EV71 obniża również fosforylację kinaz JNK (ang. c-Jun amino-terminal kinase), co wpływa na proces autofagii. Natomiast, redukcja aktywności p38 MAPK wiąże się z obniżeniem poziomu antygenu powierzchniowego HBV, białka HBsAg (ang. HBV surface antygen). Inny mechanizm działania BBR stwierdzono $\mathrm{w}$ przypadku HCV (ang. Hepatitis C virus). Może ona blokować wnikanie HCV poprzez oddziaływanie z glikoproteiną E2, znajdującą się na powierzchni wirusowej cząstki
[34]. BBR może oddziaływać na różne białka wirusowe. W przypadku wirusów z rodziny Flaviviridae, wirusa DENV oraz wirusa ZIKV wykazano, że dokuje się on do białek niestrukturalnych tych wirusów. Należą do nich metylotransferaza NS5 DENV oraz białko NS3 ZIKV. Obydwa białka są niezbędne w procesie replikacji wirusowego genomu [35]. Przypuszcza się, że BBR poprzez oddziaływania z tymi białkami może hamować proces replikacji wirusa. Dokuje się ona również do miejsca aktywnego neuraminidazy (NA) wirusa grypy, a jej aktywność przeciwwirusowa jest podobna do olseltamiviru, inhibitora NA [36]. Ostatnie badania in silico wykazały, że BBR może dokować do głównej proteazy

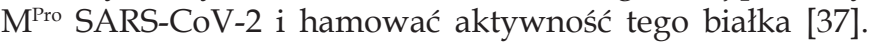
Proteaza $\mathrm{M}^{\text {Pro }}$ odgrywa kluczową rolę w potranslacyjnej obróbce białek wirusowych i jest jednym z najlepiej scharakteryzowanych białek koronawirusa, które są celem środków terapeutycznych [38].

Tabela 2. Aktywność przeciwwirusowa wybranych alkaloidów roślinnych [wg 3,13,20].

\begin{tabular}{|c|c|c|}
\hline Alkaloid & Gatunek rośliny (rodzina) & Działanie \\
\hline $\begin{array}{l}\text { Atropina } \\
\text { (ang. atropine) }\end{array}$ & Pokrzyk wilcza jagoda - Atropa belladonna L. (Solanaceae) & $\begin{array}{l}\text { Aktywność przeciwwirusowa względem } \\
\text { wirusów posiadających zewnętrzną otoczkę }\end{array}$ \\
\hline Buchapina (ang. buchapine) & Euodia roxburghiana & $\begin{array}{l}\text { Blokowanie odwrotnej } \\
\text { transkryptazy wirusa HIV-1 }\end{array}$ \\
\hline $\begin{array}{l}\text { Kofeina } \\
\text { (ang. caffeine) }\end{array}$ & $\begin{array}{l}\text { Kakaowiec właściwy - Theobroma cacao L. (Sterculiaceae) } \\
\text { Kawowiec - Coffea L. (Rubiaceae) }\end{array}$ & $\begin{array}{l}\text { Supresja wzrostu koksakiwirusa } \\
\text { (ang. Coxsackie-virus), echowirusów, } \\
\text { herpeswirusów, wirusów polio i grypy }\end{array}$ \\
\hline $\begin{array}{l}\text { Chelidonina } \\
\text { (ang. chelidonine) }\end{array}$ & $\begin{array}{l}\text { Glistnik jaskółcze ziele - Chelidonium } \\
\text { majus L. (Papaveraceae) }\end{array}$ & $\begin{array}{l}\text { Aktywność przeciwwirusowa względem } \\
\text { herpeswirusów i wirusowi grypy }\end{array}$ \\
\hline $\begin{array}{l}\text { Fagaronina } \\
\text { (ang. fagaronine) }\end{array}$ & Fagara zanthoxyloides Lam (Rutaceae) & $\begin{array}{l}\text { Inhibicja aktywności odwrotnej } \\
\text { transkryptazy retrowirusów }\end{array}$ \\
\hline $\begin{array}{l}\text { 10-metoksykamptotecyna (ang. } \\
\text { 10-methoxycamptothecin) }\end{array}$ & $\begin{array}{l}\text { Camptotheca acuminata } \\
\text { Decne (Nyssaceae) }\end{array}$ & $\begin{array}{l}\text { Inhibicja syntezy DNA i RNA, } \\
\text { aktywność przeciwwirusowa względem } \\
\text { herpeswirusów i wirusa krowianki }\end{array}$ \\
\hline $\begin{array}{l}\text { Papaweryna } \\
\text { (ang. papaverine) }\end{array}$ & $\begin{array}{l}\text { Mak lekarski - Papaver somniferum } \\
\text { (Papaveraceae) }\end{array}$ & $\begin{array}{l}\text { Blokowanie replikacji kilku typów wirusów } \\
\text { np. wirusa cytomegalii (CMV), odry, HIV }\end{array}$ \\
\hline Taspina (ang. taspine) & Croton lechleri M. (Euphorbiaceae) & $\begin{array}{l}\text { Inhibicja aktywności polimeraz RNA i DNA } \\
\text { wirusa ptasiej mieloblastozy, wirusa, } \\
\text { Rauscher oraz wirusa Simian sarcoma }\end{array}$ \\
\hline $\begin{array}{l}\text { Kastanospermina } \\
\text { (ang. castanospermine), } \\
\text { australina (ang. australine) }\end{array}$ & $\begin{array}{l}\text { Kasztanowiec australijski - Castanospermum } \\
\text { australe (Leguminosae) }\end{array}$ & $\begin{array}{l}\text { Redukcja zdolności infekowania kultur komórek } \\
\text { ludzkich przez wirus HIV, } \\
\text { Potencjalny lek na AIDS }\end{array}$ \\
\hline $\begin{array}{l}\text { Palmityna (ang. palmitine), } \\
\text { berberyna (ang. berberine), } \\
\text { kolumbamina } \\
\text { (ang. columbamine) }\end{array}$ & $\begin{array}{l}\text { Różne rodziny roślin, m.in. } \\
\text { Flaszowcowate (Annonaceae) } \\
\text { Berberys zwyczajny - Berberis vulgaris (Berberidaceae), } \\
\text { miesięcznikowate (Menispermaceae) i makowate } \\
\text { (Papaveraceae) }\end{array}$ & Aktywność przeciwwirusowa względem HIV-1 \\
\hline $\begin{array}{l}\text { Buksamina } \mathrm{E} \\
\text { (ang. buxamine E), } \\
\text { cyklobuksamina } \mathrm{H} \\
\text { (ang. cyclobuxamine } H \text { ) }\end{array}$ & $\begin{array}{l}\text { Bukszpan wieczniezielony - Buxus } \\
\text { sempervirens (Buxaceae) }\end{array}$ & Inhibicja odwrotnej transkryptazy HIV-1 \\
\hline $\begin{array}{l}\text { Fulwoplumerina (ang. fulvoplumierin), } \\
\text { kolombamina } \\
\text { (ang. columbamine), } \\
\text { fagaronina (ang. fagaronine) }\end{array}$ & $\begin{array}{l}\text { Plumeria czerwona - Plumeria rubra L. } \\
\text { (Apocynaceae) }\end{array}$ & Inhibicja odwrotnej transkryptazy HIV-1 \\
\hline
\end{tabular}


BBR, podobnie jak inne alkaloidy izochinolinowe (sangwinaryna, emetyna, $\beta$-karbolina) oraz chinolinowe (chinina, cynchomina, skimianina), interkaluje do DNA. Powoduje to stabilizacje podwójnoniciowej cząsteczki DNA, hamując replikację, trankrypcję i proces translacji. Poprzez interkalowanie do DNA lub sparowanych rejonów/struktur w cząsteczce RNA, prowadzi do zahamowania replikacji wirusowego genomu. BBR hamuje również syntezę wirusowych białek [39]. Ponadto, ekstrakt pozyskany z Coptidis rhizoma, zawierający BBR oraz inne alkaloidy protoberberynowe, hamuje syntezę RNA koronawirusów oraz składanie i uwalnianie cząstki wirusowej [40]. Chlorochina, stosowana jako lek antymalaryczny, anty-MERS-CoV (ang. Middle east respiratory syndrom coronavirus) oraz obecnie $\mathrm{w}$ terapii COVID-19, jest syntetyczną pochodną alkaloidu chininy [41]. Blokuje ona infekcję wirusową na etapie wnikania cząstki wirusowej do komórki, poprzez zwiększanie $\mathrm{pH}$ w endosomach, co sprzyja uwalnianiu wirusa w komórce oraz zaburza glikozylację receptora komórkowego dla SARS-CoV-2. Chlorochina ma też właściwości immunomodulujące, co wzmacnia działanie przeciwwirusowe [42].

W tabeli 2 zamieszczono przykłady innych alkaloidów o potwierdzonym działaniu przeciwwirusowym.

\section{ZWIĄZKI FENOLOWE}

Rośliny lecznicze, zwłaszcza te zawierające lateks, stanowią bogate źródło aktywnych biologicznie związków fenolowych. Są to roślinne metabolity wtórne, złożone pod względem struktury i właściwości, co sprawia, że trudno je usystematyzować [43]. Najczęściej zalicza się do nich proste fenole, kwasy fenolowe, kumaryny, flawonoidy, lignany, ksantony, antrachinony, stilbeny, z czego najbardziej liczne są kwasy fenolowe i flawonoidy [43]. Związki fenolowe powszechnie występują w owocach i warzywach, olejkach eterycznych, nasionach roślin, zbożach, przyprawach oraz w takich napojach, jak wino, soki owocowe, kawa, herbata [44]. Związki fenolowe mają szereg właściwości prozdrowotnych, działając zarówno profilaktycznie, jak i leczniczo. Spośród nich najważniejsze to aktywność przeciwutleniająca, przeciwzapalna, immunostymulująca, przeciwbakteryjna i przeciwwirusowa [43].

Związki fenolowe wykazują właściwości przeciwwirusowe, m.in. względem HIV, HSV, wirusów grypy, RSV, HCV, HBV i innych [45-47]. Na przykład, olejek eteryczny z tymianku pospolitego (Thymus vulgaris L.), zawierający głównie fenole, takie jak tymol i karwakrol, posiada właściwości przeciwwirusowe względem wirusa RSV i wirusa grypy typu A [48].

Związki fenolowe często wykazują wysokie powinowactwo do białek, formując z nimi niestabilne kompleksy. Dlatego przypuszcza się, że mechanizm przeciwwirusowego działania kwasów fenolowych i flawonoidów, względem m.in. wirusa HSV, polega na oddziaływaniu z glikoproteinami wirusowej otoczki lub na blokowaniu działania wirusowej polimerazy, co prowadzi do zatrzymania syntezy wirusowego genomu [49].

\section{KWASY FENOLOWE}

U roślin występują hydroksylowe pochodne kwasów fenolowych, takich jak kwasu cynamonowego (np. kwas kawowy, ferulowy) i benzoesowego (np. kwas galusowy, gentyzynowy) [50]. Kwasy fenolowe posiadają zróżnicowane właściwości farmakologiczne, takie jak aktywność przeciwzapalna, przeciwgorączkowa, przeciwbakteryjna, przeciwwirusowa, przeciwgrzybicza, immunostymulująca i żółciopędna [51].

Kwas galusowy wyizolowany $\mathrm{z}$ zatrwianu (Limonium densiflorum) wykazuje przeciwwirusowe właściwości względem wirusa HSV-1, blokując przyłączanie i wnikanie cząstek wirusowych do wnętrza komórek [47,49].

Kwas gentyzynowy z winorośli właściwej (Vitis vinifera L.) wykazuje działanie przeciwwirusowe względem herpeswirusów, takich jak PRV (ang. Pseudorabies virus) i BoHV-1 (ang. Bovine herpesvirus type 1). Molekularny mechanizm tej aktywności polega na blokowaniu przyłączania się cząstek wirusowych do powierzchni komórek (Tabela 3) [43,52,53].

\section{FLAWONOIDY}

Flawonoidy stanowią największą grupę niskocząsteczkowych związków roślinnych [54]. Związki te wykazują aktywność przeciwnowotworową, przeciwzapalną oraz przeciwwirusową względem wirusów DNA i RNA (Tabela 3) [55]. Aktywność przeciwwirusową flawonoidów wykazano na różnych etapach infekcji wirusowej. Flawonoidy mogą blokować proces przyłączania i wnikania cząstki wirusowej do komórki gospodarza. W niektórych przypadkach związki te mogą modyfikować strukturę wirionu, co zaburza odpłaszczannie cząstki wirusowej. Flawonoidy mogą być inhibitorami wczesnych etapów replikacji materiału genetycznego wirusa, blokować transkrypcję i translację oraz obróbkę potranslacyjną wirusowych białek. Aktywność przeciwwirusowa flawonoidów to również oddziaływania

Tabela 3. Zestawienie wybranych związków fenolowych (kwasów fenolowych, flawonoidów) o znanych właściwościach przeciwwirusowych.

\begin{tabular}{llll}
$\begin{array}{l}\text { Nazwa } \\
\text { Kwasy fenolowe }\end{array}$ & Pochodzenie & Aktywność przeciwwirusowa & Źródła \\
\hline Kwas galusowy & Limonium densiflorum & HSV-1 & [49] \\
\hline Kwas gentyzynowy & $\begin{array}{l}\text { Winorośl właściwa } \\
\text { (Vitis vinifera) }\end{array}$ & PRV, BoHV-1 & [52] \\
\hline Flawonoidy & Tarczyca bajkalska (Scutellaria baicalensis) & DENV-2, AH1N1, SARS-CoV & {$[63-65]$} \\
Baikalina & Zioła medycyny chińskiej & SARS-CoV-2, JEV (ang. & {$[66-68]$}
\end{tabular}


tych związków z czynnikami komórkowymi, niezbędnymi w cyklu replikacyjnym wirusa oraz działanie modulujące układ immunologiczny gospodarza [56]. Związki, takie jak kwercetyna, mirycetyna i ich pochodne hamują aktywność wirusa grypy oddziałując z hemaglutyniną na powierzchni cząstki wirusowej i blokując jej wnikanie do komórki [57], jak również hamując wczesne fazy replikacji [58]. Kwercetyna blokuje także NS3 helikazę i NS5 proteazę HCV [59]. Apigenina wykazuje aktywność przeciwwirusową względem pikornawirusów [60], EBV (ang. Epstein-Barr virus) [61] i HCV [62]. Ostatnie badania wykazały aktywność przeciwwirusową flawonoidów względem koronawirusów. Związki te blokują kluczowe enzymy zaangażowane w cykl replikacyjny, tj. PLpro, 3CLpro oraz NTPaza/helikaza [63].

\section{FENYLOPROPANOIDY}

Fenylopropanoidy stanowią zróżnicowaną grupę roślinnych metabolitów wtórnych, syntetyzowaną z fenyloalaniny lub tyrozyny poprzez serię reakcji enzymatycznych (Ryc. 3) [69]. Można znaleźć je m.in. w ziarnach zbóż (np. pszenica, jęczmień, owies, żyto, otręby ryżowe) [70,71], owocach, warzywach, kawie, przyprawach, ziołach [72-74], czy olejkach eterycznych [75] .

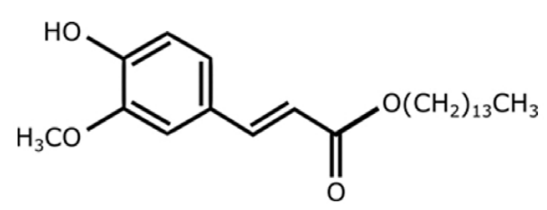

Rycina 3. Wzór strukturalny ferulanu tetradecylu jako przedstawiciela fenylopropanoidów.

Zarówno roślinne, jak i syntetyczne fenylopropanoidy oraz ich pochodne stały się obiektem zainteresowania w celu potencjalnego wykorzystania w leczeniu chorób człowieka ze względu na ich niską toksyczność i szereg biologicznych właściwości, takich jak przeciwdrobnoustrojowość [76], aktywność przeciwutleniająca [77], przeciwzapalna [78], przeciwnowotworowa [79-81] oraz przeciwwirusowa [20,82]. Ponadto, wykazują one właściwości ochronne, korzystne m.in. dla układu nerwowego [83], nerek [84, 85], wątroby [86] i serca [87].

Fenylopropanoidy wykazują aktywność przeciwwirusową m.in. względem wirusów: grypy, zapalenia wątroby typu C, HIV, HSV, polio, wirusa Epsteina-Barr i innych (Tabela 4) [88-91]. Molekularny mechanizm przeciwwirusowego działania fenylopropanoidów jest zróżnicowany i np. ferulan tetradecylu (ang. Tetradecyl ferulate) $\mathrm{z}$ bazylii azjatyckiej (Ocimum sanctum L.) blokuje aktywność odwrotnej transkryptazy wirusa HIV-1, co w konsekwencji zatrzymuje replikację wirusowego materiału genetycznego [88]. Z ko- lei, w przypadku pochodnych kwasu ferulowego i kwasu kawowego przeciwwirusowe działanie względem wirusów grypy polega na blokowaniu aktywności neuraminidazy [89, 91]. Podobnie, fenylopropanoidy z olejku eterycznego badianu właściwego (Illicium verum), zwanego anyżem gwiaździstym, wykazywały aktywność przeciwwirusową względem wirusa HSV-1, blokując wnikanie wirusowych cząstek do komórki. Przypuszcza się, że związki te mogą oddziaływać z białkami otoczki lipidowej wirusa lub ze strukturami odpowiedzialnymi za ich przyłączanie do powierzchni komórki i wnikanie do jej wnętrza [75].

\section{TERPENOIDY}

Terpenoidy stanowią jedną z najliczniejszych i najbardziej zróżnicowanych strukturalnie grup metabolitów wtórnych [92]. Wytwarzają je głównie rośliny i dotychczas zidentyfikowano ich ponad 55 tysięcy. Dodawane są do żywności jako witaminy, substancje smakowe i zapachowe [93]. Terpenoidy wykazują właściwości antybiotyczne, przeciwbakteryjne, przeciwnowotworowe, przeciwwirusowe oraz immunostymulujące, dlatego stosuje się je także $\mathrm{w}$ celach leczniczych [94]. Ich rola w roślinie polega m.in. na regulowaniu wzrostu i rozwoju oraz udziale w oddziaływaniach pomiędzy roślinami i odpowiedzi obronnej na patogeny czy szkodniki $[92,95,96]$. Bogatym źródłem terpenoidów jest: koper włoski, melisa, szałwia, kolendra, soja i inne warzywa strączkowe, marchew, szpinak, buraki [97].

Terpenoidy wykazują właściwości przeciwwirusowe względem wirusów grypy, Epsteina-Barr, HIV, polio, HSV i innych (Tabela 5) [20]. Wykazano, że izoborneol, składnik roślinnych olejków eterycznych z szałwii, inaktywuje wirusa HSV-1, oddziałując z lipidami wirusowej otoczki oraz hamuje glikozylację wirusowych białek. Skutkuje to utratą infekcyjności wirusa HSV-1 [98]. Podobne właściwości posiadają także inne monoterpenowe związki obecne w olejku z szałwii, takie jak tujon i 1,8-cyneol [99]. Wykazano również aktywność przeciwwirusową terpenoidów z szałwii (Salvia officinalis) względem wirusa pęcherzykowego zapalenia jamy ustnej (VSV ang. Vesicular stomatitis virus) oraz HSV-1 [100].

Mieszanina monoterpenoidów z olejku drzewa herbacianego, w której skład wchodziły terpinen-4-ol, a-terpineol, linalol, 1,8-cyneol, działała przeciwwirusowo względem wirusów grypy. Ponadto, wykazano lecznicze działanie tej mieszaniny na opryszczkę spowodowaną wirusem Herpesvirus hominis [101,102].

Triterpeny z kory brzozy (Betula alba), takie jak betulina, kwas betulinowy, kwas oleanolowy, wykazują aktywność przeciwwirusową względem wirusa zapalenia mózgu i mięśnia sercowego (EMCV, ang. Encephalomyocarditis virus)

Tabela 4. Wybrane przykłady fenylopropanoidów roślinnych oraz wirusy na które oddziałują.

$\begin{array}{llll}\text { Fenylopropanoid } & \text { Pochodzenie } & \text { Aktywność przeciwwirusowa } & \text { Źródła } \\ \begin{array}{l}\text { Mieszanina fenylopropanoidów } \\ \text { z olejku eterycznego }\end{array} & \text { badian właściwy (Illicium verum) } & \text { HSV-1 } & \text { [75] } \\ \text { Ferulan tetradecylu } & \text { bazylia azjatycka (Ocimum sanctum } \text { L.) } & \text { HIV } & \text { [88] } \\ \text { N-oleylcaffeamide } & \text { bazylia azjatycka (Ocimum sanctum L.) } & \text { HIV } & {[88]}\end{array}$




\begin{tabular}{|c|c|c|c|}
\hline Terpenoid & Pochodzenie & $\begin{array}{l}\text { Właściwości } \\
\text { przeciwwirusowe }\end{array}$ & Źródła \\
\hline Izoborneol & szałwia grecka (Salvia fruticosa) & HSV-1 & {$[47]$} \\
\hline Tujon & szałwia grecka (Salvia fruticosa) & HSV-1 & {$[47]$} \\
\hline $\begin{array}{l}\text { Mieszanina monoterpenoidów: terpinen- } \\
\text { 4-ol, a-terpineol, linalol, 1,8-cyneol }\end{array}$ & $\begin{array}{l}\text { drzewo herbaciane } \\
\text { (Melaleuca alternifolia) }\end{array}$ & wirusy grypy & {$[106]$} \\
\hline Norperovskatone & $\begin{array}{l}\text { perowskia łobodolistna } \\
\text { (Perovskia atriplicifolia) }\end{array}$ & HBV & {$[106]$} \\
\hline Biperovskatone & $\begin{array}{l}\text { perowskia łobodolistna } \\
\text { (Perovskia atriplicifolia) }\end{array}$ & $\mathrm{HBV}$ & {$[106]$} \\
\hline Betulina & Brzoza brodawkowata (Betula alba) & EMCV, VSV & {$[103]$} \\
\hline
\end{tabular}

oraz VSV. Związki te są słabo rozpuszczalne w wodzie, dlatego mechanizm ich działania może polegać na pokrywaniu cząstek wirusowych przez warstwę wytrąconych triterpenów [103]. Może to blokować wirusowe struktury, które są niezbędne do przyłączania i wnikania wirusa do komórki gospodarza, co w konsekwencji uniemożliwia infekcję. Kwas betulinowy pochodzący z czapetki (Syzigium claviflorum) wykazywał również hamujący wpływ na replikacje wirusa HIV-1 in vitro [104]. Triterpenoidowe saponiny, typu oleananu i ursanu, hamowały replikację wirusa HSV-1 in vitro. Saponiny typu oleananu hamowały syntezę nici DNA wirusa HSV-1, a saponiny typu ursanu prawdopodobnie blokowały syntezę wirusowych białek strukturalnych [105].

Przedstawione właściwości przeciwwirusowe terpenoidów wskazują, że jest to jedna $\mathrm{z}$ grup naturalnych związków roślinnych, którą można potencjalnie wykorzystać $\mathrm{w}$ leczeniu wirusowych chorób człowieka.

\section{CHINONY}

Chinony są to metabolity wtórne roślin o właściwościach przeciwwirusowych, ale też cytotoksycznych. Należą do nich antrachinony, naftochinony i benzochinony. Wykazano ich przeciwwirusową aktywość względem wirusów DNA i RNA, np. herpeswirusów HHV-1, HHV-8 (ang. human herpesvirus) oraz wirusa Dengi serotyp 2 (DENV-2, ang. Dengue virus serotype 2). Chinon 27 terpenyl-1,4-naftochinon (NQ) zaburza wiązanie się cząstki HHV-1 do komórek gospodarza oraz może wiązać się z glikoproteiną E DENV-2 [107]. Oprócz zaburzania adsorbcji i wnikania wirusa do komórki, związki te działają na replikację oraz transkrypcję wirusowego genomu, jak też wpływają na aktywność enzymów niezbędnych do cyklu replikacyjnego wirusa [108, 109]. 9,10-antrachinon (emodin) izolowany z korzenia rabarbaru dłoniastego (Rheum tanguticum) hamuje replikacje herpeswirusów, blokuje białko UL12, zaangażowane w rozplatanie cząsteczki DNA, oraz zaburza proces fosforylacji wirusowych białek poprzez blokowanie niektórych enzymów [110]. Dendinobin, inny związek z grupy chinonów, blokuje promotor LTR HIV-1 oraz czynnik NF-kB, prowadząc do hamowania wirusowej transkrypcji [111]. Również związki z grupy naftochinonów wykazują działanie przeciwwirusowe względem HIV, blokując działanie integrazy oraz fuzję cząstki wirusowej z limfocytami T CD4 [112]. Roślinne antrachinony, znajdujące się $\mathrm{w}$ ekstrakcie $\mathrm{z}$ aloesu
(Aloe vera), wykazują aktywność przeciwwirusową względem HBV poprzez mechanizm blokowania wirusowej polimerazy [113]. Aloin, główny antrachinon izolowany z Aloe sp., wykazuje aktywność przeciwwirusową względem wirusa grypy A (H1N1) poprzez blokowanie wirusowej neuraminidazy [114]. Działanie przeciwwirusowe względem wirusów zawierających osłonięte wiriony, jak wirus grypy typu A, oraz wirusów niemających otoczki, jak np. enterowirus 71 wykazuje antrachinon izolowany $\mathrm{z}$ aloesu - aloe-emodin $[115,116]$.

\section{TANINY}

Taniny to wtórne metabolity roślinne, należące do grupy polifenoli. Związki te wchodzą $\mathrm{w}$ interakcje $\mathrm{z}$ białkami, głównie poprzez oddziaływania hydrofobowe i wiązania wodorowe [117]. Przejawiają także aktywność przeciwwirusową względem licznych wirusów. Wykazano, że taniny mogą hamować wnikanie do komórki wirusa HIV-1 poprzez oddziaływania z wirusowym białkiem gp41 [118], a także hamować syntezę białka p24, co z kolei wstrzymuje replikację tego wirusa. Związki te uniemożliwiają także fuzję komórek zakażonych wirusem HIV-1 [119].

Taniny wyizolowane z rośliny Combretum molle R. Br. Ex G. Don (Combretaceae) hamują aktywność odwrotnej transkryptazy HIV-1 [120,121], a także replikację wirusa HIV, poprzez oddziaływania na aktywność proteazy oraz integrazy wirusa [122]. Z kolei, tanina izolowana z Tithonia diversifolia (Hemsl.) A. Gray (Asteraceace) hamuje oddziaływania pomiędzy wirusowym białkiem płaszcza gp120 a receptorem komórkowym CD4 [123].

Przykładem związku z grupy tanin jest kwas chebulagowy. Wyizolowany z owoców rośliny Terminalia chebula, wykazuje aktywność przeciwwirusową względem wirusa EV71 [124] oraz uniemożliwia wiązanie wirusa herpes HSV-1 i HSV-2 do komórki $[125,126]$. Przypuszcza się, że aktywność przeciwwirusowa tych związków łączy się z ich oddziaływaniem $\mathrm{z}$ wirusowymi glikoproteinami powierzchniowymi, co z kolei blokuje oddziaływanie wirusa z komórką, jego adsorpcję i penetrację do komórki.

Kwas chebulagowy wykazuje aktywność przeciwwirusową również względem wirusa zapalenia wątroby typu C (HCV) [127] i wirusa HIV in vitro [128]. 
Wysokocząsteczkowe taniny oraz kwas taninowy, wyizolowane z kory Hamamelis virginiana L. (Hamamelidaceae), wykazywały aktywność przeciwwirusową względem ludzkiego wirusa brodawczaka typu 16 (HPV, ang. Human Papillomavirus) i grypy), wiążąc się z receptorami komórek docelowych. Ponadto, związki te hamują aktywność wirusowej neuraminidazy [117]. Aktywność tę hamują również kwas galusowy, galusan epigallokatechiny oraz hamamelitanina [117], natomiast sam kwas taninowy uniemożliwia adsorpcję wirusa HSV do komórki [129].

Galusan epigallokatechiny (EGCG ang. epigallocatechin-3-gallate) (Ryc. 4) przejawia aktywność przeciwwirusową względem wirusów HCV, HIV oraz grypy [130-132]. Wykazano, że związek ten może łączyć się z kieszenią powstałą w wyniku oddziaływania glikoproteiny 120 wirusa HIV z receptorem CD4 komórek T [133]. EGCG wiąże się także z białkami powierzchniowymi wirusa IAV, jak również powoduje sklejanie cząstek wirusa IAV poza powierzchnią komórki.<smiles>O=C(O[C@H]1Cc2c(O)cc(O)cc2OC1(c1cc(O)c(O)c(O)c1)c1cc(O)c(O)c(O)c1)c1cc(O)c(O)c(O)c1</smiles>

Rycina 4. Galusan epigallokatechiny (EGCG).

Aktywność przeciw wielu wirusom - w tym grypy H3N2 i H5N3, herpes HSV-1, pęcherzykowego zapalenia jamy ustnej, Sendaj (SeV, ang. Sendai virus), choroby Newcastle (NDV, ang. Newcastle disease virus), polio i Coxsackie [134] - wykazuje także tanina persymonu, izolowana z owoców Diospyros kaki. Z kolei, tanina izolowana z zielonej herbaty powodowała zahamowanie replikacji wirusów grypy i HSV-1 [135].

Oenoteina B hamuje replikację wirusów HIV i HSV. Została wydzielona z rośliny Oenothera erythrosepala Borbas [136].

Natomiast, kwas galusowy, izolowany z rośliny Terminalia chebula Retz., Combretaceae, hamuje aktywności integrazy oraz odwrotnej transkryptazy HIV [20], a wydzielone z Eugenia uniflora eugenifloryny $\mathrm{D}(1)$ i $\mathrm{D}(2)$ hamują polimeraze DNA wirusa Epsteina-Barr (EBV) [137].

\section{TIOFENY I POLIACETYLENY}

Tiofeny i poliacetyleny, podobnie jak taniny, są wtórnymi metabolitami roślinnymi. Mają wspólne szlaki biosyntezy.
Cechują się aktywnością przeciwwirusową, która często jest skorelowana z budową chemiczną danego związku.

PHT (phenylheptatriyne), wyizolowany z Bidens pilosa, jest poliacetylenem, który wykazuje aktywność przeciwwirusową względem wirusa Sindbis (SINV, ang. Sindbis virus) pod wpływem działania światła UV. Na działanie PHT szczególnie podatne są wirusy z osłoniętymi wirionami [138].

Ponadto, jeden z tiofenów - alfa-tertienyl, izolowany z roślin z rodziny Asteraceae, także wykazuje aktywność przeciw wirusowi SINV. Tiofen ten oddziałuje na nienasycone lipidy błony komórkowej oraz białka błonowe [139].

Poliacetylen ditiacykloheksadienu (ang. Thiarubrine A) (Ryc. 5), izolowany z liści Aspilia pluriseta Schweinf. (Compositae), hamuje oddziaływania pomiędzy glikoproteiną gp120 płaszcza wirusa HIV-1 i HIV-2 a receptorem CD4, znajdującym się na powierzchni komórki, co uniemożliwia adsorpcję wirusowej cząstki do komórki $[123,140,141]$. Poliacetyleny hamują także aktywność odwrotnych transkryptaz onkogennych retrowirusów [142].

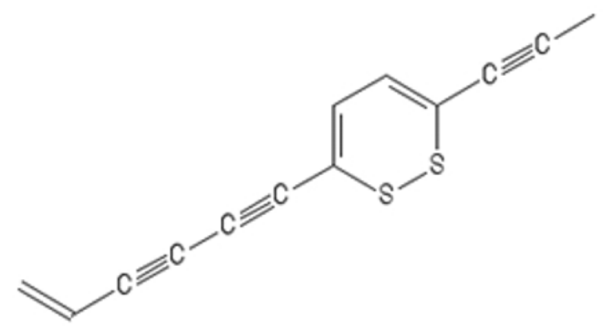

Rycina 5. Poliacetylen ditiacykloheksadienu.

\section{LIGNINY}

Ligniny stanowią trzeci (po celulozie i hemicelulozie) najbardziej rozpowszechniony polimer na Ziemi [143]. Związki te są ważnymi składnikami ściany komórkowej roślin. Zapewniają one integralność, fizyczne wzmocnienie, jak również zwiększają wytrzymałość i sztywność ściany, a ze względu na swoją hydrofobowość czynią ją nieprzepuszczalną dla wody [143-145]. Są one również elementem mechanizmów obronnych rośliny, stanowiąc fizyczną i chemiczną barierę dla patogenów. Ponadto wykazano, że w odpowiedzi na atak patogenów dochodzi do ekspresji roślinnych genów kodujących monolignole [144].

Ligniny zbudowane są z monomerów będących pochodnymi alkoholi fenolowych, głównie alkoholu koniferylowego, synapinowego i kumarylowego, połączonych często z innymi związkami w skomplikowane sieci $[145,146]$. Struktura chemiczna, tworzone połączenia, masa molekularna i dystrybucja lignin zależą od gatunku oraz wieku rośliny $[143,147]$. Związki te budzą zainteresowanie ze względu na swoją aktywność biologiczną i właściwości antyoksydacyjne, przeciwnowotworowe, przeciwwirusowe, przeciwbakteryjne i immunostymulujące $[143,147]$.

Oczyszczona frakcja składająca się z lignin, pochodząca z szyszek sosny drobnokwiatowej (Pinus paroiflora), hamu- 
je proces infekcji wirusa grypy w testach komórkowych. Frakcja ta hamuje zarówno syntezę białek wirusowych, jak i aktywność wirusowej polimerazy RNA zależnej od RNA [148]. Natomiast, frakcja ligninowa pochodząca z twardnika japońskiego (Lentinus edodes) wykazuje aktywność przeciwwirusową względem wirusa HIV [149].

Niskocząsteczkowe ligniny, będące produktem ich degradacji, wykazują aktywność przeciwwirusową względem wirusów HCV oraz HIV-1. Związki te blokują możliwość wejścia do komórki wirusa HCV [150]. Mogą one również hamować replikację wirusa HIV, poprzez supresję transkrypcji i aktywację szlaków zależnych od NF-kB [151]. Działanie lignin skierowane przeciwko wirusowi HIV-1 może wynikać także z uniemożliwienia adsorpcji lub zablokowania zdolności wirusa do replikacji [143,152].

Kwas lignosulfonowy (LA) jest polianionową makromolekułą, pochodną lignin. Liczne badania wykazały, że LA to tani, nietoksyczny związek o właściwościach przeciwwirusowych potwierdzonych $\mathrm{w}$ testach in vitro oraz in vivo $[147,153]$. Wiąże się on $\mathrm{z}$ wirusowym białkiem otoczki gp120, uniemożliwiając wnikanie wirusa do komórek, co ogranicza transmisję i infekcyjność HIV-1 [147,154]. Ponadto, hamuje on również wnikanie do komórek wirusa HSV-2 $[5,12]$.

Kompleksy ligninocelulozowe (LCC) to trwałe kowalencyjnie połączone ligniny i węglowodany, rozpuszczalne $\mathrm{w}$ wodzie. Frakcja zawierająca LCC, pochodząca z głowienki pospolitej (Prunella vulgaris L.) oraz sosny drobnokwiatowej (Pinus parviflora), w testach in vitro i in vivo wykazuje aktywność skierowaną przeciwko wirusom HSV-1 i HSV-2 [155157]. Blokuje ona bezpośrednio wiązanie i penetrację HSV1 do komórek Vero [156]. Zablokowanie wnikania wirusa HSV-1 potwierdzono również po zastosowaniu polimerów ligniny zsyntetyzowanych z kwasu kawowego i ferulowego [158]. Antywirusową aktywność przeciwko wirusom HSV1, HSV-2, cytomegalii (HCMV) i wirusowi odry wykazują również LCC pochodzące $\mathrm{z}$ anyżu (Pimpinella anisum), które blokują adsorpcję i penetrację do komórek, jak też mogą inaktywować wirusy m.in. w wyniku aktywacji produkcji tlenku azotu (NO) [159]. Liczne badania $\mathrm{w}$ testach in vitro wykazują również działanie tych związków (m.in. wyeks- trahowanych z ziaren kakaowca) przeciwko wirusowi HIV1 [160-161]. Ponadto, ligninocelulozy mogą blokować replikację pikornawirusa zapalenia mózgu i mięśnia sercowego (EMCV, ang. Encephalomyocarditis virus) [162]

Nanoligniny są produktami powstałymi poprzez transformację polimerów do formy koloidalnych cząsteczek ligniny. Wykazano, że w wodzie związki te powodują agregację i łatwe usuwanie cząstek wirusa CCMV (ang. Cowpea chlorotic mottle virus). Dzięki tej właściwości mogą zostać użyte jako materiał do oczyszczania wody z kontaminacji wirusami $[163,164]$.

\section{INNE ROŚLINNE CZYNNIKI PRZECIWWIRUSOWE}

Do związków o aktywności przeciwwirusowej należy także eleonat wapnia - inhibitor odwrotnej transkryptazy wirusa HIV. Związek ten występuje w korzeniach i korze drzewa oliwnego (Olea europaea L.) [165]. Właściwości przeciwwirusowe względem wirusa HIV wykazują również siarczany polisacharydów, takie jak siarczan dekstranu izolowany z fiołka japońskiego (Viola yedoensis), czy siarczan dekstrinu pozyskiwany $\mathrm{z}$ alternantery krokodylowej ( $\mathrm{Al}$ ternanthera philoxeroides). Związki te wchodzą w interakcje z wirusową glikoproteiną gp120, hamując oddziaływanie wirusa z komórką gospodarza, wirusową replikację oraz tworzenie syncytiów [166]. Synteza glikolipidów i glikoprotein osłonki wirusa ospy, opryszczki jest hamowana przez glukozaminy izolowane z soi warzywnej (Glycine max) czy z fasoli złotej (Phaeseolus aureus) [166].

\section{LEKTYNY}

Właściwości przeciwwirusowe wykazują także lektyny. Prawie wszystkie dotychczas poznane lektyny roślinne są glikoproteinami, których część cukrowa zbudowana jest najczęściej z cząstek mannozy i glukozaminy. Wyjątek stanowi konkanawalina A, izolowana z konwalii, w której nie stwierdzono cukrów. Lektyny są białkami wiążącymi specyficzne reszty cukrowe i nie wykazują aktywności enzymatycznej. Wszystkie poznane zawierają dwa lub więcej miejsc wiążących jednostki cukrowe, co tłumaczy ich zdolność do aglutynowania erytrocytów i innych komórek. Ponadto, pobudzają do proliferacji limfocyty poprzez zwięk-

Tabela 6. Przeciwwirusowa aktywność lektyn roślinnych [wg 167].

\begin{tabular}{lll}
\hline Lektyna & Roślina, źródło lektyny & Aktywność przeciwwirusowa \\
\hline Jacalin & $\begin{array}{l}\text { chlebowiec różnolistny } \\
\text { (Artocarpus integrifolia) }\end{array}$ & względem HIV, oddziałuje na glikany CD4 \\
BanLec & banan (Musa acuminate) & HIV oddziałuje z białkiem \\
gp120, HCV, H1N1, H3N2
\end{tabular}


szenie syntezy i uwalnianie limfokin. Występują głównie w roślinach strączkowych.

Wykazano, że liczne lektyny hamują namnażanie wirusów, oddziałując na glikproteiny wirusowych osłonek (Tabela 6).

\section{ROŚLINNE ZWIĄZKI MODULUJĄCE AKTYWNOŚĆ UKŁADU ODPORNOSCIOWEGO}

Liczne związki roślinne są naturalnymi immunostymulatorami, jak również supresorami układu odpornościowego. Preparaty roślinne o działaniu immunomodulacyjnym określa się jako modyfikatory odpowiedzi biologicznej (BMR, ang. biological response modifiers).

Immunostymulatory roślinne można podzielić na związki drobnocząsteczkowe, do których zalicza się m.in.: alkaloidy, kwasy fenolokarboksylowe, chinony, seskwiterpeny, laktony, lignany, izobutyloamidy, fenole, fosfatydy, estry forbolu i wielkocząsteczkowe, takie jak: pektyny, polisacharydy, nukleotydy, proteiny i heteroglikany.

Właściwości takie wykazują również roślinne fruktany typu inuliny (ITFs ang., inulin-type fructans) czy białka arabinogalaktanowe (AGP, ang. arabinogalactan proteins) [168]. Na przykład, ekstrakty wodne, czy etanolowe, jak również polisacharydy z jeżówki (Echinacea purpurea, E. angustifolia, E. pallida) stymulują funkcjonowanie układu odpornościowego, hamując stan zapalny poprzez blokowanie ekspresji białka NF-kBp65 [169,170]. Aktywność immunomodulująca fruktanów zależy od receptorów TLR (ang. Toll-likereceptors), przede wszystkim TLR2 i w mniejszym stopniu TLR4, 5, 7, 8 [168]. Fruktany zwiększają również syntezę tlenku azotu, który hamuje replikację wirusów oraz interleukin immunostymulujących (IL-1 $\beta$, IL-6, IL-10), interferonu gamma (IFN Y), TNF-a (ang. tumor necrosis factor alfa). Źródłem fruktanów jest cebula walijska (Allium fistulosum L.), wykazująca silne działanie przeciwwirusowe względem wirusa grypy, czosnek (Allium satioum), cebula (Allium cepa), yacon (Smallanthus sonchifolius), kurkuma (Curcuma kwangsiensis), bylica pospolita (Artemisia vulgaris) [168].

Rośliny bogate we fruktany mają właściwości immunomodulujace poprzez ich działanie jako przeciwutleniacze. Silne właściwości przeciwwirusowe, względem wirusów powodujących zakażenia górnych dróg oddechowych, wykazuje jeżówka (Echinacea). Funkcjonowanie przeciwwirusowe związków izolowanych z tej rośliny stanowi wynik ich synergistycznego działania immunomodulującego, przeciwzapalnego oraz jako przeciwutleniacza [171]. Właściwości immunomodulujące wykazują także wspomniane białka arabinogalaktanowe (AGP), glikoproteiny ściany komórkowej roślin bogate $\mathrm{w}$ hydroksyprolinę. Jest to grupa bardzo zróżnicowanych białek zbudowanych ze szkieletu białkowego (ok. 10\% masy białka), do którego dołączona jest cząsteczka węglowodanu (90\% masy), najczęściej zawierającego reszty arabinozy i galaktozy, rzadziej fruktozy, ksylozy i kwasu glukuronowego. Większość reszt hydroksyproliny jest glikozylowana przez arabino-3,6 galaktany $[172,173]$. Białka te aktywują makrofagi oraz stymulują wzrost proliferacji limfocytów T i B układu odpornościo- wego. AGP izolowane były z roślin różnych gatunków. Ich bogatym źródłem jest kawa arabska (Coffea arabica L.), z której AGP silnie stymulowały wydzielanie TNF alfa i IL2. Z kolei, białka izolowane z jeżówki purpurowej (Echinacea purpurea) stymulowały wydzielanie TNF-a, IL-1 i IFN- $\beta$ $[174,175]$. Silnymi immunostymulatorami są także arabinoglikany z modrzewia, które stymulowały syntezę prozapalnych cytokin oraz aktywowały makrofagi i komórki NK (ang. natural killers) [176]. Źródłem AGP w diecie człowieka może być por, marchew, chrzan, kukurydza, czy pomidory. Związki te są także obecne w jeżówce i kurkumie (Curcuma longa) [176]. Najwięcej związków o działaniu immunomodulującym wyizolowano z roślin należących do rodziny astrowatych, np. jeżówki purpurowej (Echinacea purpurea), sadźca (Eupatorium sp.), ale także znajdujących się w roślinach innych rodzin, jak np. w rosiczce okrągłolistnej (Drosera rotundifolia) [176].

W ostatnich latach duże zainteresowanie budzą roślinne białka PR (ang. pathogenesis-related proteins), syntetyzowane $\mathrm{w}$ roślinie $\mathrm{w}$ celu obrony przed czynnikami stresowymi.

\section{BIAŁKA ROŚLINNE ZWIĄZANE Z PATOGENEZĄ}

Jednym $\mathrm{z}$ elementów odpowiedzi roślin na stres, $\mathrm{w}$ tym zakażenia wirusowe, jest indukcja syntezy białek PR związanych z patogenezą. Akumulacja tych białek stanowi integralny składnik wrodzonej odpowiedzi obronnej roślin podczas ataku patogenów lub w warunkach stresu abiotycznego. Białka PR nie tylko gromadzą się lokalnie w zakażonej części rośliny, ale również są związane z rozwojem reakcji nadwrażliwości (HR, ang. hypersensitive response) lub nabytej odporności systemicznej (SAR, ang. systemic acquired resistance) na zakażenie grzybami, bakteriami i wirusami [177]. Białka te dzielimy na 17 rodzin, w zależności od ich struktury pierwszorzędowej, właściwości antygenowych i aktywności biologicznej [178]. Różne rodziny białek PR wykazują odmienne aktywności enzymatyczne: przeciwgrzybowe (PR-1), chitynazy (PR-3, PR-4, PR-8 i PR-11) [179, 180], $\beta$-1,3-glukanazy (PR-2) [179], osmotyny/ białka taumatyno-podobne (PR-5), rybonukleazy (PR-10), defensyny (PR-12) [181], tioniny (PR-13), białka przenoszące lipidy (PR-14) i oksydazy szczawianowe (PR-15, PR-16) [177,182,183]. Większość białek PR ma charakter zewnątrzkomórkowy, ale niektóre są białkami cytoplazmatycznymi, a część kierowana jest do wakuoli [178].

W kontekście potencjalnych aktywności przeciwwirusowych najważniejsza jest rodzina białek PR-10 - największa spośród wszystkich białek PR [178]. Zidentyfikowano je u wielu gatunków roślin. Są to niewielkie białka o masie cząsteczkowej w zakresie 15-18 kDa, charakterze kwasowym, odporne na działanie proteaz.

Białka PR-10 biorą udział w wielu aspektach rozwoju, wzrostu i obrony roślin, ale ich funkcja molekularna nadal nie została wyjaśniona.

W roślinie są one syntetyzowane pod wpływem różnych warunków stresowych, a w niektórych przypadkach objawiały się konstytutywnie [184]. Białka PR-10 wykazują strukturalną homologię do rybonukleazy. Po raz pierw- 
szy odkryto je w grochu i pietruszce pod koniec lat 80 . XX wieku [178]. Białka PR-10 mają zdolność cięcia kwasów nukleinowych, co spełnia dwie funkcje: cięcie materiału genetycznego patogena (np. wirusowego DNA lub RNA) oraz materiału genetycznego komórki, co skutkuje zaprogramowaną jej śmiercią w miejscu zakażenia. Aktywność rybonukleazy została udowodniona dla białka Bet v $1 \mathrm{z}$ brzozy (Betula verrucosa), rekombinowanego białka CaPR-10 z papryki rocznej (Capsicum annuum) [185], białka LaPR-10 z łubinu (Lupinus albus) [186], PR-10c z brzozy (Betula pendula) [187]. Struktura białka Bet v 1 z brzozy i białka PR-10 z łubinu żółtego umożliwiła identyfikację 3 reszt, które przypuszczalnie biorą udział w aktywności rybonukleazy: E96, E148, Y150. Ich bliskość prawdopodobnie przekłada się na obecność aktywnego miejsca reakcji katalitycznej [178].

Białka PR-10 są częstymi alergenami odpowiedzialnymi za alergię na pyłek brzozy, jednak podobne zostały zidentyfikowane w selerze, jabłku, wiśni, orzeszkach ziemnych, pomidorach czy marchwi [188,189]. Wszystkie białka typu Bet v 1 wykazują podobieństwa strukturalne i mają w swojej cząsteczce dużą kieszeń hydrofobową, która może łączyć niskocząsteczkowe związki hydrofobowe, takie jak kwasy tłuszczowe, flawonoidy i cytokininy. Kieszeń ta może być zatem ważna dla funkcji fizjologicznych Bet v 1 [164].

Inną grupą białek roślinnych zdolnych do wiązania kwasów nukleinowych są białka bogate w glicynę, wiążące RNA (GRP, ang. glycine-rich RNA-binding proteins). GRP to duża nadrodzina heterogennych białek, które zawierają zachowawcze domeny bogate w reszty glicyny. Glicyna może stanowić między 20 a 70\% wszystkich aminokwasów w cząsteczkach GRP. Pierwotnie odkryto je u petunii (ponad 30 lat temu) i do tej pory znaleziono je u wielu gatunków, w tym sinic, roślin i zwierząt [190,191]. Opisano różne funkcje białek GRP, w tym wiązanie RNA, interakcje z innymi białkami i udział w odpowiedziach obronnych przeciwko bodźcom stresowym biotycznym i abiotycznym [192]. Ich poziom w roślinie zmienia się po zakażeniu. Ponadto, na poziom białek GRP mogą wpływać infekcje wywoływane przez patogeny [192]. Białka GRP znaleziono w ścianach komórkowych roślin, gdzie wraz z bogatymi w prolinę białkami i ekstensynami pełnią rolę komponentów strukturalnych (podklasy IVa-IVd) [191,193].

Jedną z roślin, w których zidentyfikowano GRP jest Chelidonium majus L. [194]. W lateksie tego gatunku stwierdzono obecność białka GRP, nazwanego CmGRP1, zaliczanego do klasy IVa roślinnych GRP i białek RBP (ang. RNA-binding proteins) [195]. Oznacza to, że oprócz domeny bogatej w glicynę zawiera również motywy rozpoznające RNA (RRM, ang. RNA recognition motifs). RBP kontrolują przetwarzanie RNA i stabilizują mRNA wywołane stresem [194,196]. Rośliny wykorzystują RBP do ochrony przed wirusami. Na przykład, kilka białek RBP gospodarza hamowało replikację, transport i translację wirusowego RNA, poprzez specyficzne interakcje [197].

Do innych białek przeciwwirusowych roślin należą białka inaktywujące rybosomy (RIPs, ang. ribosome-inactivating proteins). Występują one powszechnie w różnych gatunkach roślin i mogą hamować translację poprzez enzymatyczne uszkodzenie rybosomów [198,199], specyficznie hydrolizując wiązania N-glikozydowe w ściśle określonych nukleozydach w rRNA (adenozynie lub guanozynie). Wykazują również aktywność chitynazy, lipazy, dysmutazy ponadtlenkowej, DNazy i RNazy [200]. Ich fizjologiczne role mogą być związane z reakcjami obronnymi przeciwko drapieżnikom, grzybom, a przede wszystkim wirusom, ze względu na aktywność N-glikozydazy wobec wirusowego RNA. Z uwagi na tę samą aktywność N-glikozydazy wobec genomowego DNA roślin, RIP mogą również odgrywać rolę $\mathrm{w}$ starzeniu się roślin [200,201].

\section{PODSUMOWANIE}

Liczne rośliny stanowią cenne źródło związków o właściwościach leczniczych, w tym przeciwwirusowych i przeciwnowotworowych. Wytwarzane w nich metabolity wtórne wykorzystywane są od dawna do otrzymywania leków naturalnych, których historia sięga początków cywilizacji. W ostatnich latach odnotowuje się zwiększone zainteresowanie związkami roślinnymi, które mogą nie tylko wspomagać leczenie, ale także zapobiegać rosnącej liczbie chorób, w tym chorób wirusowych. Uważa się, że skuteczność lecznicza preparatów roślinnych opiera się na wzajemnym oddziaływaniu związków biologicznie aktywnych. Ostatnie badania nad tymi związkami wskazują, że mogą one również np. blokować aktywność wirusowych białek enzymatycznych, w wyniku dokowania w ich miejsca aktywne czy blokowania oddziaływań z komórką gospodarza. Z tego względu bardzo ważne jest poznanie struktury takich cząsteczek, ich powierzchni oraz reszt bioracych udział $\mathrm{w}$ tych oddziaływanich. Bardzo pomocne $\mathrm{w}$ tych badanich są metody bioinformatyczne pozwalające na przewidzenie możliwości oddziaływania niskocząsteczkowych związków z białkami wirusowymi czy komórkowymi (tzw. molekularne dokowanie) [202]. Większość poznanych dotychczas związków roślinnych ma dość szeroki zakres działania. Wyizolowane z roślin pojedyncze związki mogą wykazywać również odmienne działanie niż cały ekstrakt. $\mathrm{Na}$ aktywność substancji biologicznie aktywnych w leku znacząco może wpływać sposób uprawy, przechowywanie zebranych materiałów roślinnych, suszenie, a także metoda ekstrakcji. Związki roślinne najczęściej wykazują przeciwwirusowe działanie względem różnych wirusów - np. kwercetyna hamuje replikcję wirusa grypy, rinowirusów, Epsteina-Barr, zapalenia wątroby typu C. Mechanizm tej aktywności jest również odmienny i nie do końca poznany. Na przykład, kwercetyna hamuje replikację wirusa zapalenia wątroby typu $C$ poprzez oddziaływanie na wirusowe białka NS5A i NS3, natomiast rinowirusa - poprzez hamowanie procesu endocytozy, transkrypcji, translacji wirusowego materiału genetycznego [203].

Warunkiem szerszego wykorzystania związków roślinnych w terapii przeciwwirusowej jest także poznanie molekularnego sposobu ich działania. Inną trudnością związaną $\mathrm{z}$ ich stosowaniem jest niska rozpuszczalność $\mathrm{w}$ wodzie $\mathrm{i}$ niska biodostępność. Do dostarczania ich próbuje się stosować: nanocząstki, micele, mikrosfery i kryształy, stałą dyspersję, systemy samo-, mikro- i nano-emulgujące (SNEDDS, ang. self-nanoemulsifying drug delivery systems i SMEDDS, ang. self-microemulsifying drug delivery systems). 


\section{PIŚMIENNICTWO}

1. Soltan MM, Zaki AK (2009) Antiviral screening of forty-two Egyptian medicinal plants. J Ethnopharmacol 125: 102-107

2. Ben-Shabat S, Yarmolinsky L, Porat D, Dahan A (2020) Antiviral effect of phytochemicals from medicinal plants: Applications and drug delivery strategies. Drug Deliv Transl Res 10: 354-367

3. Perez RM (2003) Antiviral activity of compouns isolated from plants. Pharmaceutical Biology 41: 107-157

4. Fiore C, Eisenhut M., Krausse, Ragazzi E, Pellati D, Armanini D, Bielenberg J (2008) Antiviral effects of Glycyrrhiza species. Phytother Res 22: $141-148$

5. Dhawan BN (2012) Anti-viral activity of Indian plants. Proc Natl Acad Sci Sect B Biol Sci 82: 209-224

6. Desselberger U (1995) Molecular Epidemiology, W: Desselberger U (red) Medical Virology: A Practical Approach. Oxford University Press, New York, str. 173-190

7. Wawer I (2020) Roślinne preparaty przeciwwirusowe do wspomagania organizmu w czasie infekcji górnych dróg oddechowych. Fitoterapia 30: 6-15

8. Bribi N (2018) Pharmacological activity of alkaloids: A Review. Asian J Bot 1: doi:10.63019/ajb.v1i2.467

9. Adejoke HT, Louis H, Amusan OO, Apebende G (2019) A review on classes, extraction, purification and pharmaceutical importance of plants alkaloid. J Med Chem Sci 2: 130-139

10. Thawabteh A, Juma S, Bader M, Karaman D, Scrano L, Bufo SA, et al. (2019) The biological activity of natural alkaloids against herbivores, cancerous cells and pathogens. Toxins (Basel) 11: 656

11. Kurapati KRV, Atluri VS, Samikkannu T, Garcia G, Nair MPN (2016) Natural products as Anti-HIV agents and role in HIV-Associated neurocognitive disorders (HAND): a brief overview. Front Microbiol 6: 1444

12. Valadão ALC, Abreu CM, Dias JZ, Arantes P, Verli H, Tanuri A, et al. (2015) Natural plant alkaloid (Emetine) inhibits HIV-1 replication by interfering with reverse transcriptase activity. Molecules 20: 1147411489

13. Ravanelli N, Santos KP, Motta LB, Lago JHG, Furlan CM (2016) Alkaloids from Croton echinocarpus Baill.: Anti-HIV potential. South Afr J Bot 102: 153-156

14. Bunteang S, Chanakul W, Hongthong S, Kuhakarn C, Chintakovid W, Sungchawek N, et al. (2018) Anti-HIV Activity of alkaloids from Dasymaschalon echinatum. Nat Prod Comm 13: 29-32

15. Moradi MT, Karimi A, Lorigooini Z (2018) Alkaloids as the natural anti-influenza virus agents: a systematic review. Toxin Rev 37: 11-18

16. Cavalcanti JF, de Araujo MF, Gonçalves PB, Romeiro NC, Villela Romanos MT, Curcino Vieira IJ, et al. (2018) Proposed anti-HSV compounds isolated from Simira species. Nat Prod Res 32: 2720-2723

17. Treml J, Gazdová M, Šmejkal K, Šudomová M, Kubatka P, Hassan STS (2020) Natural products-derived chemicals: breaking barriers to novel Anti-HSV drug development. Viruses 12: 154

18. Hutterer C, Milbradt J, Hamilton S, Zaja M, Leban J, Henry C, et al. (2017) Inhibitors of dual-specificity tyrosine phosphorylation-regulated kinases (DYRK) exert a strong anti-herpesviral activity. Antivir Res 143: $113-121$

19. Benzekri R, Bouslama L, Papetti A, Hammami M, Smaoui A, Limam F (2018) Anti HSV-2 activity of Peganum harmala (L.) and isolation of the active compound. Microb Pathog 114: 291-298

20. Abad MJ, Guerra JA, Bermejo P, Irurzun A, Carrasco L (2000) Search for antiviral activity in higher plant extracts. Phytother Res 14: 604-607

21. Troost B, Mulder LM, Diosa-Toro M, van de Pol D, Rodenhuis-Zybert IA, Smit JM (2020) Tomatidine, a natural steroidal alkaloid shows antiviral activity towards chikungunya virus in vitro. Sci Rep 10: 6364

22. Warowicka A, Nawrot R, Goździcka-Józefiak A (2020) Antiviral activity of berberine. Arch Virol 165: 1935-1945

23. Yan YQ, Fu YJ, Wu S, Qin HQ, Zhen X, Song BM, et al. (2018) Anti-influenza activity of berberine improves prognosis by reducing viral replication in mice. Phytother Res 32: 2560-2567
24. Varghese FS, Kaukinen P, Gläsker S, Bespalov M, Hanski L, Wennerberg K, et al. (2016) Discovery of berberine, abamectin and ivermectin as antivirals against chikungunya and other alphaviruses. Antiviral Res 126: 117-124

25. Wang H, Li K, Ma L, Wu S, Hu J, Yan H, et al. (2017) Berberine inhibits enterovirus 71 replication by downregulating the MEK/ERK signaling pathway and autophagy. Virol J 14: 2

26. Shin HB, Choi MS, Yi CM, Lee J, Kim NJ, Inn KS (2015) Inhibition of respiratory syncytial virus replication and virus-induced p38 kinase activity by berberine. Int Immunopharmacol 27: 65-68

27. Hayashi K, Minoda K, Nagaoka Y, Hayashi T, Uesato S (2007) Antiviral activity of berberine and related compounds against human cytomegalovirus. Bioorg Med Chem Lett 17: 1562-1564

28. Chin LW, Cheng YW, Lin SS, Lai YY, Lin LY, Chou MY, et al. (2010) Anti-herpes simplex virus effects of berberine from Coptidis rhizoma, a major component of a Chinese herbal medicine, Ching-Wei-San. Arch Virol 155(12): 1933-41

29. Pizzorno A, Padey B, Dubois J, Julien T, Traversier A, Dulière V, et al. (2020) In vitro evaluation of antiviral activity of single and combined repurposable drugs against SARS-CoV-2. Antiviral Res 181: 104878

30. Neag MA, Mocan A, Echeverría J, Pop RM, Bocsan CI, Crişan G, et al. (2018) Berberine: botanical occurrence, traditional uses, extraction methods, and relevance in cardiovascular, metabolic, hepatic, and renal disorders. Front Pharmacol 9:557 doi: 10.3389/fphar.2018.00557. eCollection 2018

31. Song S, Quin M, Chu Y, Chen D, Su A, Wu Z (2014) Downregulation of cellular c-JUN N terminal protein kinase and NF-kB activation by berberine may result in inhibition of herpes simplex virus replication. Antimicrob Agents Chemother 58(9): 5068-5078

32. Varghese FS, Thaa B, Amrun SN, Simarmata D, Rausalu K, Nyman TA, et al. (2016) The antiviral alkaloid berberine reduces Chikungunya virus-induced mitogen-activated protein kinase signaling. J Virol 90: 9743-9757

33. Botwina P, Owczarek K, Rajfur Z, Ochman M, Urlik M, Nowakowska $M$, et al. (2020) Berberine hampers influenza a replication through inhibition of MAPK/ERK pathway. Viruses 12: 344

34. Hung TC, Jassey A, Liu CH, Lin CJ, Lin CC, Wong SH, et al. (2019) Berberine inhibits hepatitis $C$ virus entry by targeting the viral $\mathrm{E} 2$ glycoprotein. Phytomedicine 53: 62-69

35. Srivastava V (2018) Quinacrine and berberine as antiviral agents against dengue and zika fever: In silico approach. Biostat Bioinform 1: 12

36. Enkhtaivan G, Muthuraman P, Kim DH, Mistry B (2017) Discovery of berberine based derivatives as anti-influenza agent through blocking of neuraminidase. Bioorg Med Chem 25: 5185-5193

37. Narkhede RR, Pise AV, Cheke RS, Shinde SD (2020) Recognition of natural products as potential inhibitors of COVID-19 main protease (Mpro): In-silico evidences. Nat Prod Bioprospect 10: 297-306

38. Zhang L, Lin D, Sun X, Curth U, Drosten C, Sauerhering L, et al. (2020) Crystal structure of SARS-CoV-2 main protease provides a basis for design of improved a-ketoamide inhibitors. Science 368: 409-412

39. Varghese FS, Kaukinen P, Gläsker S, Bespalov M, Hanski L, Wennerberg K, et al. (2016) Discovery of berberine, abamectin and ivermectin as antivirals against chikungunya and other alphaviruses. Antiviral Res 126: 117-124

40. Kim HY, Shin HS, Park H, Kim YC, Yun YG, Park S, et al. (2008) In vitro inhibition of coronavirus replications by the traditionally used medicinal herbal extracts, Cimicifuga rhizoma, Meliae cortex, Coptidis rhizoma, and Phellodendron cortex. J Clin Virol 41: 122-128

41. Bleasel MD, Peterson GM (2020) Emetine, ipecac, ipecac alkaloids and analogues as potential antiviral agents for coronaviruses. Pharmaceuticals 13: 51

42. Wang M, Cao R, Zhang L, Yang X, Liu J, Xu M, et al. (2020) Remdesivir and chloroquine effectively inhibit the recently emerged novel coronavirus (2019-nCoV) in vitro. Cell Res 30: 269-271

43. Kasprzak K, Oniszczuk A (2017) Właściwości farmakologiczne związków polifenolowych, W: Panfil M (red) Badania i Rozwój Młodych 
Naukowców w Polsce - Nauki przyrodnicze, część I. Młodzi Naukowcy, Poznań, str. 61-67

44. Kozłowska H, Troszyńska A (1999) Rola naturalnych substancji nieodżywczych pochodzenia roślinnego jako składników żywności funkcjonalnej. Żywność. Nauka. Technologia. Jakość. 4(21)S: 63-74

45. Chávez JH, Leal PC, Yunes RA, Nunes RJ, Barardi CR, Pinto AR, et al. (2006) Evaluation of antiviral activity of phenolic compounds and derivatives against rabies virus. Vet Microbiol 116: 53-59

46. Wu YH, Zhang BY, Qiu LP, Guan RF, Ye ZH, Yu XP (2017) Structure properties and mechanisms of action of naturally originated phenolic acids and their derivatives against human viral infections. Curr Med Chem. 24: 4279-4302

47. Özçelik B, Kartal M, Orhan I (2011) Cytotoxicity, antiviral and antimicrobial activities of alkaloids, flavonoids, and phenolic acids. Pharm Biol 49: 396-402

48. Rochalska M, Orzeszko-Rywka A (2009) Zastosowanie naturalnych substancji roślinnych jako zapraw nasiennych dla upraw ekologicznych. J Res Appl Agric Eng 54: 74-79

49. Medini F, Megdiche W, Mshvildadze V, Pichette A, Legault J, St-Gelais A, et al. (2016) Antiviral-guided fractionation and isolation of phenolic compounds from Limonium densiflorum hydroalcoholic extract. C R Chim 19: 726-732

50. Parus A (2013) Przeciwutleniające i farmakologiczne właściwości kwasów fenolowych. Post Fitoter 1: 48-53

51. Mróz P, Wilczek K, Żak M, Zielińska-Pisklak M (2012) Chromatograficzne metody izolacji i identyfikacji fenolokwasów. Biul Wydz Farm WUM 6: 40-48

52. Lisov A, Vrublevskaya V, Lisova Z, Leontievsky A, Morenkov O (2015) A 2, 5-Dihydroxybenzoic acid-gelatin conjugate: The synthesis, antiviral activity and mechanism of antiviral action against two alphaherpesviruses. Viruses 7: 5343-5360

53. Perez R.M (2003) Antiviral activity of compounds isolated from plants. Pharm Biol 41: 107-157

54. Takshak S (2018) Bioactive compounds in medicinal plants: A condensed review. SEJ Pharm Nat Med. 1: 1-35

55. Panche AN, Diwan AD, Chandra SR (2016) Flavonoids: An overview. J Nutr Sci. 5:e47

56. Lalani S, Poh CL (2020) Flavonoids as antiviral agents for enterovirus A71 (EV-A71). Viruses 12: 184

57. Wu W, Li R, Li X, He J, Jiang S, Liu S, et al. (2015) Quercetin as an antiviral agent inhibits influenza A virus (IAV) entry. Viruses 8: 6

58. Choi HJ, Song JH, Park KS, Kwon DH (2009) Inhibitory effects of quercetin 3-rhamnoside on influenza A virus replication. Eur J Pharm Sci 37: 329-333

59. Lu N, Khachatoorian R, French SW (2012) Quercetin: bioflavonoids as part of interferon-free hepatitis $C$ therapy? Expert Rev Anti Infect Ther 10: 619-621

60. Dai W, Bi J, Li F, Wang S, Huang X, Meng X, et al. (2019) Antiviral efficacy of flavonoids against enterovirus 71 infection in vitro and in newborn mice. Viruses 11: 625

61. Wu CC, Fang CY, Cheng YJ, Hsu HY, Chou SP, Huang SY, et al. (2017) Inhibition of Epstein-Barr virus reactivation by the flavonoid apigenin. J Biomed Sci. 24: 2

62. Shibata C, Ohno M, Otsuka M, Kishikawa T, Goto K, Muroyama R, et al. (2014) The flavonoid apigenin inhibits hepatitis $C$ virus replication by decreasing mature microRNA levels. Virology 462-463: 42-48

63. Russo M, Moccia S, Spagnuolo C, Tedesco I, Russo GL (2020) Roles of flavonoids against coronavirus infection. Chem Biol Interact 328: 109211

64. Moghaddam E, Teoh BT, Sam SS, Lani R, Hassandarvish P, Chik Z, et al. (2014) Baicalin, a metabolite of baicalein with antiviral activity against dengue virus. Sci Rep 4: 5452

65. Li R, Wang L (2019) Baicalin inhibits influenza virus A replication via activation of type I IFN signaling by reducing miR-146a. Mol Med Rep 20: $5041-5049$
66. Huang YF, Bai C, He F, Xie Y, Zhou H (2020) Review on the potential action mechanisms of Chinese medicines in treating Coronavirus Disease 2019 (COVID-19). Pharmacol Res 158: 104939

67. Chojnacka K, Witek-Krowiak A, Skrzypczak D, Mikula K, Młynarz P (2020) Phytochemicals containing biologically active polyphenols as an effective agent against Covid-19-inducing coronavirus. J Funct Foods 73: 104146

68. Fan W, Qian S, Qian P, Li X (2016) Antiviral activity of luteolin against Japanese encephalitis virus. Virus Res 220: 112-116

69. Kumar S, Sumner B, Sumner LW (2020) Modern plant metabolomics for the discovery and characterization of natural products and their biosynthetic genes. Compr Nat Prod III. 7: 156-188

70. Schmidt CG, Goncalves LM, Prietto L, Hackbart HS, Furlong EB (2014) Antioxidant activity and enzyme inhibition of phenolic acids from fermented rice bran with fungus Rizhopus oryzae. Food Chem 146: 371-377

71. Zielinski H, Kozlowska H, Lewczuk B (2001) Bioactive compounds in the cereal grains before and after hydrothermal processing. Innov Food Sci Emerg Technol 2: 159-169

72. Maurya DK, Devasagayam TPA (2010) Antioxidant and prooxidant nature of hydroxycinnamic acid derivatives ferulic and caffeic acids. Food Chem Toxicol 48: 3369-3373

73. Teixeira J, Silva T, Benfeito S, Gaspar A, Garrido EM, Garrido J, et al. (2013) Exploring nature profits: Development of novel and potent lipophilic antioxidants based on galloyl-cinnamic hybrids. Eur J Med Chem 62: 289-296

74. Devi A, Das VK, Deka D (2018) Evaluation of the effectiveness of potato peel extract as a natural antioxidant on biodiesel oxidation stability. Ind Crops Prod 123: 454-460

75. Astani A, Reichling J, Schnitzler P (2011) Screening for antiviral activities of isolated compounds from essential oils. Evid Based Complement Alt Med 2011: 253643

76. Kępa M, Miklasinska-Majdanik M, Wojtyczka RD, Idzik D, Korzeniowski K, Smolen-Dzirba J, et al. (2018) Antimicrobial potential of caffeic acid against Staphylococcus aureus clinical strains. Biomed Res Int 2018: 1-9

77. Jia Y, He Y, Lu F (2018) The structure-antioxidant activity relationship of dehydrodiferulates. Food Chem 269: 480-485

78. Doss HM, Dey C, Sudandiradoss C, Rasool MK (2016) Targeting inflammatory mediators with ferulic acid, a dietary polyphenol, for the suppression of monosodium urate crystal-induced inflammation in rats. Life Sci 148: 201-210

79. Bouzaiene NN, Kilani Jaziri S, Kovacic H, Chekir-Ghedira L, Ghedira K, Luis J (2015) The effects of caffeic, coumaric and ferulic acids on proliferation, superoxide production, adhesion and migration of human tumor cells in vitro. Eur J Pharmacol 766: 99-105

80. Rathee D, Lather V, Grewal AS, Dureja H (2018) Targeting matrix metalloproteinases with novel diazepine substituted cinnamic acid derivatives: Design, synthesis, in vitro and in silico studies. Chem Cent J 12: 14- 21

81. Kabała-Dzik A, Rzepecka-Stojko A, Kubina R, Jastrzębska-Stojko Z, Stojko R, Wojtyczka R, Stojko J (2017) Migration rate inhibition of breast cancer cells treated by caffeic acid and caffeic acid phenethyl ester: An in vitro comparison study. Nutrients 9: 1144

82. Neelam, Khatkar A, Sharma KK (2019) Phenylpropanoids and its derivatives: biological activities and its role in food, pharmaceutical and cosmetic industries. Crit Rev Food Sci Nutr 60: 2655-2675

83. Deshmukh R, Kaundal M. Bansal V, Samardeep (2016) Caffeic acid attenuates oxidative stress, learning and memory deficit in intra-cerebroventricular streptozotocin induced experimental dementia in rats. Biomed Pharmacother 81: 56-62

84. Matboli M, Eissa S, Ibrahim D, Hegazy MGA, Imam SS, Habib EK (2017) Caffeic acid attenuates diabetic kidney disease via modulation of autophagy in a high-fat diet/streptozotocin-induced diabetic rat. Sci Rep 7: 2263 
85. Tohamy AA, Aref AM, Moneim AEA, Sayed RH (2016) Cinnamic acid attenuates cisplatin-induced hepatotoxicity and nephrotoxicity. J Bas Environ Sci 3: 1-9

86. Cha H, Lee S, Lee JH, Park J-W (2018) Protective effects of p-coumaric acid against acetaminophen-induced hepatotoxicity in mice. Food Chem Toxicol 121: 131-139

87. Chowdhury S, Ghosh S, Rashid K, Sil PC (2016) Deciphering the role of ferulic acid against streptozotocin-induced cellular stress in the cardiac tissue of diabetic rats. Food Chem Toxicol 97: 187-198

88. Sonar VP, Corona A, Distinto S, Maccioni E, Meleddu R, Fois B, et al. (2017) Natural product-inspired esters and amides of ferulic and caffeic acid as dual inhibitors of HIV-1 reverse transcriptase. Eur J Med Chem 130: 248-260

89. Xie Y, Huang B, Yu K, Shi F, Liu T, Xu W (2013) Caffeic acid derivatives: A new type of influenza neuraminidase inhibitors. Bioorganic Med Chem Lett 23: 3556-3560

90. Hariono M, Abdullah N, Damodaran KV, Kamarulzaman EE, Mohamed N, Hassan SS, et al. (2016) Potential new H1N1 neuraminidase inhibitors from ferulic acid and vanillin: Molecular modelling, synthesis and in vitro assay. Sci Rep 6: 38692

91. Amano R, Yamashita A, Kasai H, Hori T, Miyasato S, Saito S, et al. (2017) Cinnamic acid derivatives inhibit hepatitis $C$ virus replication via the induction of oxidative stress. Antivir Res 145: 123-130

92. Kowalczyk T, Łucka M, Szemraj J, Sakowicz T (2015) Terapeutyczny potencjał metabolitów wtórnych produkowanych w kulturach korzeni włośnikowatych. Post Hig Med Dosw 69: 549-561

93. Aharoni A, Jongsma MA, Kim TY, Ri MB, Giri AP, Verstappen FW, Schwab W, Bouwmeester HJ (2006) Metabolic engineering of terpenoid biosynthesis in plants. Phytochem Rev 5: 49-58

94. Muszyńska B, Sułkowska-Ziaja K, Ekiert H (2010) Główne grupy związków i pierwiastki z aktywnością biologiczną w wybranych gatunkach grzybów z taksonu Basidiomycota. Farm Pol 66: 804-814

95. Blande JD, Li T, Holopainen JK (2011) Air pollution impedes plantto-plant communication, but what is the signal? Plant Signal Behav 6: 1016-1018

96. Luan JB, Yao DM, Zhang T, Walling LL, Yang M, Wang YJ, et al. (2013) Suppression of terpenoid synthesis in plants by a virus promotes its mutualism with vectors. Ecol Lett 16: 390-398

97. Zalega J, Szostak-Węgierek D (2013) Żywienie w profilaktyce nowotworów. Część I. Polifenole roślinne, karotenoidy, błonnik pokarmowy. Probl Hig Epidemiol 94: 41-49

98. Armaka M, Papanikolaou E, Sivropoulou A, Arsenakis M (1999) Antiviral properties of isoborneol, a potent inhibitor of herpes simplex virus type 1. Antivir Res 43: 79-92

99. Sivropoulou A, Nikolaou C, Papanikolaou E, Kokkini S, Lanaras T, Arsenakis M (1997) Antimicrobial, cytotoxic, and antiviral activities of Salvia fructicosa essential oil. J Agric Food Chem 45: 3197-3201

100. Tada M, Okuno K, Chiba K, Ohnishi E, Yoshii T (1994) Antiviral diterpenes from Salvia officinalis, Phytochemistry 35: 539-541

101. Trytek M, Paduch R, Fiedurek J, Kandefer-Szerszeń M (2007) Monoterpeny-stare związki, nowe zastosowania i biotechnologiczne metody ich otrzymywania. Biotechnologia 1(76): 135-155

102. Król SK, Skalicka-Woźniak K, Kandefer-Szerszeń M, Stepulak A (2013) Aktywność biologiczna i farmakologiczna olejków eterycznych w leczeniu i profilaktyce chorób infekcyjnych. Post Hig Med Dosw 67: 1000-1007

103. Kamińska T, Kaczor J, Rzeski W, Wejksza K, Kandefer-Szerszeń M, Witek M (2004) A comparison of the antiviral activity of three triterpenoids isolated from Betula alba bark. Ann Univ Mariae Curie-Skłodowska, Lublin-Polonia, 59: 1-7

104. Hashimoto F, Kashiwada Y, Cosentino LM, Chen CH, Garrett PE, Lee KH (1997) Anti-AIDS agents-27. Synthesis and anti-HIV activity of betulinic acid and dihydrobetulinic acid derivatives. Bioorg Med Chem 5: 2133-2143

105. Simoes CM, Amoros M, Girre L (1999) Mechanism of antiviral activity of triterpenoid saponins. Phytother Res 13: 323-328
106. Jiang Z-Y, Zhou J, Huang C-G, Hu Q-F, Huang X-Z, Wang W, et al. (2015) Two novel antiviral terpenoids from the cultured Perovskia atriplicifolia. Tetrahedron 71: 3844-3849

107. Roa-Linares VC, Miranda-Brand Y, Tangarife-Castaño V, Ochoa R, García PA, Castro MÁ, et al. (2019) Anti-herpetic, anti-dengue and antineoplastic activities of simple and heterocycle-fused derivatives of terpenyl-1,4-naphthoquinone and 1,4-anthraquinone. Molecules 24: 1279

108. Alam Z, Al-Mahdi Z, Zhu Y, McKee Z, Parris DS, Parikh HI, et al. (2015) Anti-cytomegalovirus activity of the anthraquinone atanyl blue PRL. Antivir Res 114: 86-95

109. Chu JJ, Lee RC, Ang MJ, Wang WL, Lim HA, Wee JL, et al. (2015) Antiviral activities of 15 dengue NS2B-NS3 protease inhibitors using a human cell-based viral quantification assay. Antivir Res 118: 68-74

110. Xiong HR, Luo J, Hou W, Xiao H, Yang ZQ (2011) The effect of emodin, an anthraquinone derivative extracted from the roots of Rheum tanguticum, against herpes simplex virus in vitro and in vivo. J Ethnopharmacol 133: 718-23

111. Sánchez-Duffhues G, Calzado MA, de Vinuesa AG, Caballero FJ, Ech-Chahad A, Appendino G, et al. (2008) Denbinobin, a naturally occurring 1,4-phenanthrenequinone, inhibits HIV-1 replication through an NF-kappaB-dependent pathway. Biochem Pharmacol 76: $1240-1250$

112. Koyama J (2006) Anti-infective quinone derivatives of recent patents. Recent Pat Antiinfect Drug Discov 1: 113-125

113. Parvez MK, Al-Dosari MS, Alam P, Rehman M, Alajmi MF, Alqahtani AS (2019) The anti-hepatitis B virus therapeutic potential of anthraquinones derived from Aloe vera. Phytother Res 33: 2960-2970

114. Huang CT, Hung CY, Hseih YC, Chang CS, Velu AB, He YC, et al. (2019) Effect of aloin on viral neuraminidase and hemagglutinin-specific T cell immunity in acute influenza. Phytomedicine 64: 152904

115. Li SW, Yang TC, Lai CC, Huang SH, Liao JM, Wan L, et al. (2014) Antiviral activity of aloe-emodin against influenza A virus via galectin-3 up-regulation. Eur J Pharmacol 738: 125-132

116. Lin CW, Wu CF, Hsiao NW, Chang CY, Li SW, Wan L, et al. (2008) Aloe emodin is an interferon-inducing agent with antiviral activity against Japanese encephalitis virus and enterovirus 71. Int J Antimicrob Agents 32: 355-359

117. Theisen LL, Erdelmeier CAJ, Spoden GA, Boukhallouk F, Sausy A, Florin L, et al. (2014) Tannins from hamamelis virginiana bark extract: Characterization and improvement of the antiviral efficacy against influenza a virus and human papillomavirus. PloS One 9: e88062

118. Collins RA, Ng TB, Fong WP, Wan CC, Yeung HW (1997) A comparison of human immunodeficiency virus type 1 inhibition by partially purified aqueous extracts of chinese medicinal herbs. Life Sci 60: PL345-PL351

119. Lü L, Liu S-W, Jiang S-B, Wu S-G (2004) Tannin inhibits HIV-1 entry by targeting gp41. Acta Pharmacol Sin 25: 213-218

120. Bessong PO, Obi CL, Andréola M-L, Rojas LB, Pouységu L, Igumbor E, et al. (2005) Evaluation of selected South African medicinal plants for inhibitory properties against human immunodeficiency virus type 1 reverse transcriptase and integrase. J Ethnopharmacol 99: 83-91

121. Jordaan M, Van Wyk AE, Maurin O (2011) A conspectus of Combretum (Combretaceae) in southern Africa, with taxonomic and nomenclatural notes on species and sections. Bothalia 41: 135-160

122. Xu HX, Wan M, Dong H, But PP, Foo LY (2000) Inhibitory activity of flavonoids and tannins against HIV-1 protease. Biol Pharm Bull 23: 1072-1076

123. Cos P, Hermans N, De BT, Apers S, Sindambiwe JB, Witvrouw M, et al. (2002) Antiviral activity of Rwandan medicinal plants against human immunodeficiency virus type-1 (HIV-1). Phytomed 9: 62-68

124. Yang Y, Xiu J, Liu J, Zhang L, Li X, Xu Y, et al. (2013) Chebulagic acid, a hydrolyzable tannin, exhibited antiviral activity in vitro and in vivo against human enterovirus 71. Int J Mol Sci 14: 9618-9627 
125. Kesharwani A, Polachira SK, Nair R, Agarwal A, Mishra NN, Gupta SK (2017) Anti-HSV-2 activity of Terminalia chebula Retz extract and its constituents, chebulagic and chebulinic acids. BMC Complement Altern Med 17: 110

126. Lin L-T, Chen T-Y, Chung C-Y, Noyce RS, Grindley TB, McCormick C, et al. (2011) Hydrolyzable tannins (chebulagic acid and punicalagin) target viral glycoprotein-glycosaminoglycan interactions to inhibit herpes simplex virus 1 entry and cell-to-cell spread. J Virol 85: 4386-4398

127. Li Y, Yu S, Liu D, Proksch P, Lin W (2012) Inhibitory effects of polyphenols toward HCV from the mangrove plant Excoecaria agallocha $\mathrm{L}$. Bioorg Med Chem Lett 22: 1099-1102

128. Nonaka G, Nishioka I, Nishizawa M, Yamagishi T, Kashiwada Y, Dutschman GE, et al. (1990) Anti-AIDS agents, 2: Inhibitory effects of tannins on HIV reverse transcriptase and HIV replication in H9 lymphocyte cells. J Nat Prod 53: 587-595

129. Fukuchi K, Sakagami H, Okuda T, Hatano T, Tanuma S, Kitajima K, et al. (1989) Inhibition of herpes simplex virus infection by tannins and related compounds. Antivir Res 11: 285-297

130. Ciesek S, von Hahn T, Colpitts CC, Schang LM, Friesland M, Steinmann J, et al. (2011) The green tea polyphenol, epigallocatechin-3-gallate, inhibits hepatitis C virus entry. Hepatol 54: 1947-1955

131. Song J-M, Lee K-H, Seong B-L (2005) Antiviral effect of catechins in green tea on influenza virus. Antivir Res 68: 66-74

132. Nance CL, Shearer WT (2003) Is green tea good for HIV-1 infection? J Allergy Clin Immunol 112: 851-853

133. Williamson MP, McCormick TG, Nance CL, Shearer WT (2006) Epigallocatechin gallate, the main polyphenol in green tea, binds to the T-cell receptor, CD4: Potential for HIV-1 therapy. J Allergy Clin Immunol 118: 1369-1374

134. Ueda K, Kawabata R, Irie T, Nakai Y, Tohya Y, Sakaguchi T (2013) Inactivation of pathogenic viruses by plant-derived tannins: strong effects of extracts from persimmon (Diospyros kaki) on a broad range of viruses. PLoS One 8: e55343

135. Hatano T, Yasuhara T, Matsuda M, Yazaki K, Yoshida T, Okuda T (1989) Oenothein B, a dimeric hydrolyzable tannin of cyclic structure. Chem Pharm Bull 37: 2269-2271

136. Yadav IK, Jaiswal D, Singh HP, Mishra A, Jain DA (2009) Anti - HIV drugs from natural sources. The Pharm Res 1: 93-109

137. Lee MH, Chiou JF, Yen KY, Yang LL (2000) EBV DNA polymerase inhibition of tannins from Eugenia uniflora. Cancer Lett 154: 131-136

138. Hudson J, Graham E, Chan G, Finlayson A, Towers G (1986) Comparison of the antiviral effects of naturally occurring thiophenes and polyacetylenes. Planta Med 6: 453-457

139. Marles RJ, Hudson JB, Graham EA, Soucy-Breau C, Morand P, Compadre RL, et al. (1992) Structure-activity studies of photoactivated antiviral and cytotoxic tricyclic thiophenes. Photochem Photobiol 56: 479-487

140. Prinsloo G, Marokane CK, Street RA (2018) Anti-HIV activity of southern African plants: Current developments, phytochemistry and future research. J Ethnopharmacol 210: 133-155

141. Rodriguez E, Aregullin M, Nishida T, Uehara S, Wrangham R, Abramowski Z, et al. (1985) Thiarubrine A, a bioactive constituent of Aspilia (Asteraceae) consumed by wild chimpanzees. Experientia 41: $419-420$

142. Tan GT, Pezzuto JM, Douglas Kinghorn A, Hughes SH (1991) Evaluation of natural products as inhibitors of human immunodeficiency virus type 1 (HIV-1) reverse transcriptase. J Nat Prod 54: 143-154

143. Martinez V, Mitjans M, Pilar Vinardell M (2012) Pharmacological applications of lignins and lignins related compounds: An overview. Curr Org Chem 16: 1863-1870

144. Oeyena M, Noppena S, Vanhullea M, Claesa S, Myrvoldb BO, Vermeirea $K$, et al. (2019) A unique class of lignin derivatives displays broad anti-HIV activity by interacting with the viral envelope. Vir Res 274: 197760
145. Spiridon I (2020) Extraction of lignin and therapeutic applications of lignin-derived compounds. A review. Environ Chem Lett 18: 771785

146. Espinoza-Acosta JL, Torres-Chávez PI, Ramírez-Wong B, LópezSaiz CM, Montaño-Leyva B (2016) Antioxidant, antimicrobial, and antimutagenic properties of technical lignins and their applications. BioResources 11: 5452-5481

147. Vinardell VP, Mitjans M (2017) Lignins and their derivatives with beneficial effects on human health. Int J Mol Sci 18: 1219

148. Harada H, Sakagami H, Nagata K, Oh-hara T, Kawazoe Y, Ishihama A, et al. (1991) Possible involvement of lignin structure in anti-influenza virus activity. Antivir Res 15: 41-49

149. Suzuki H, Iiyama K, Yoshida O, Yamazaki S, Yamamoto N, Toda S (1990) Structural characterization of the immunoactive and antiviral water-solubilized lignin in an extract of the culture medium of Lentinus edodes mycelia (LEM). Agric Biol Chem 54: 479-487

150. Matsuhisa K, Yamane S, Okamoto T, Watari A, Kondoh M, Matsuura Y, et al. (2015) Anti-HCV effect of Lentinula edodes mycelia solid culture extracts and low-molecular-weight lignin. Biochem Biophys Res Commun 462: 52-57

151. Mitsuhashi S, Kishimoto T, Uraki Y, Okamoto T, Ubukata M (2008) Low molecular weight lignin suppresses activation of NF-kappaB and HIV-1 promoter. Bioorg Med Chem 16: 2645-2650

152. Nakashimaa H, Murakamia T, Yamamotoa N, Sakagamib H, Tanumac S, Hatanod T, et al. (1992) Inhibition of human immunodeficiency viral replication by tannins and related compounds. Antivir Res 18: 91-103

153. Qiu M, Wang Q, Chu Y, Yuan Z, Song H, Chen Z, et al. (2012) Lignosulfonic acid exhibits broadly anti-HIV-1 activity - potential as a microbicide candidate for the prevention of HIV-1 sexual transmission. PLoS ONE 7: e35906

154. Gordts SC, Férir G, D’Huys T, Petrova MI, Lebeer S, Snoeck R, et al. (2015) The Low-Cost Compound Lignosulfonic Acid (LA) Exhibits broad-spectrum Anti-HIV and Anti-HSV activity and has potential for microbicidal applications. PLoS One 10: e0131219

155. Xu HX, Lee SH, Lee SF, White RL, Blay J (1999) Isolation and characterization of an anti-HSV polysaccharide from Prunella vulgaris. Antivir Res 44: 43-54

156. Zhang Y, But PP-H, Eng-Choon Ooi V, Xu HX, Delaney GD, Lee SHS, Lee SF (2007) Chemical properties, mode of action, and in vivo anti-herpes activities of a lignin-carbohydrate complex from Prunella vulgaris. Antivir Res 75: 242-249

157. López BSG, Yamamoto M, Sakagami H (2012) Treatment of herpes simplex virus with lignin-carbohydrate complex tablet, an alternative therapeutic formula. Antiviral Drugs - Aspects of Clinical Use and Recent Advances. DOI:10.5772/32975

158. Thakkar JN, Tiwari V, Desai UR (2010) Non-sulfated, cinnamic acid-based lignins are potent antagonists of HSV-1 entry into cells. Biomacromolecules 11: 1412-1416

159. Lee JB, Yamagishi C, Hayashi K, Hayashi T (2011) Antiviral and immunostimulating effects of lignin-carbohydrate-protein complexes from Pimpinella anisum. Biosci Biotechnol Biochem 75: 459-465

160. Sakagami H, Kawano M, Thet MM, Hashimoto K, Satoh K, Kanamoto T, et al. (2011) Anti-HIV and immunomodulation activities of cacao mass lignin-carbohydrate complex. In Vivo 25: 229-236

161. Sakagami H (2014) Biological activities and possible dental application of three major groups of polyphenols. J Pharmacol Sci126: 92-106

162. Kimura C, Li R, Ouda R, Nishimura H, Fujita T, Watanabe T (2020) Production of antiviral substance from sugarcane bagasse by chemical alteration of its native lignin structure through microwave solvolysis. Chem Sus Chem 13: 4519-4527

163. Rivière GN, Korpi A, Sipponen MH, Zou T, Kostiainen MA, Österberg M (2020) Agglomeration of viruses by cationic lignin particles for facilitated water purification. ACS Sustain Chem Eng 8: $4167-4177$ 
164. Srisapoome P, Hamano K, Tsutsui I, Iiyama K (2018) Immunostimulation and yellow head virus (YHV) disease resistance induced by a lignin-based pulping by-product in black tiger shrimp (Penaeus monodon Linn.). Fish Shellfish Immunol 72: 494-501

165. Heinze JE, Hale AH, Carl PL (1975) Specificity of the antiviral agent calcium eleonate. Antimicrob Agents Chemother 8: 421-425

166. Kaluza G, Scholtlssek C, Rott R (1972) Inhibition of the multiplication of enveloped RNA-viruses by glucosamine and 2-deoxy-D-glucose. J Gen Virol 14: 251-259

167. Mitchell CA, Ramessar K, O'Keefe BR (2017) Antiviral lectins: Selective inhibitors of viral entry. Antivir Res 142: 37-54

168. Dobrange E, Peshev D, Loedolff B, Van den Ende W (2019) Fructans as immunomodulatory and antiviral agents: The case of Echinacea. Biomolecules 9: 615

169. Pillai S, Pillai C, Mitscher LA, Cooper R (2007) Use of quantitative flow cytometry to measure ex vivo immunostimulant activity of Echinacea: The case for polysaccharides. J Altern Complement Med 13: 625-634

170. Yuan DQ, Yuan Y, Jiang L, Tai YL, Yang XN, Hu F, et al. (2013) Anti-inflammatory effects of essential oil in Echinacea purpurea L. Pak J Pharm Sci 26: 403-408

171. Vogt L, Ramasamy U, Meyer D, Pullens G, Venema K, Faas MM, et al. (2013) Immune modulation by different types of beta 2-> fructans is toll-like receptor dependent. PLoS ONE 8: e68367

172. Ellis M, Egelund J, Schultz CJ, Bacic A (2010) Arabinogalaktan-proteins: key regulator at the cell surface? 153: 403-419

173. Olmos E,De LaGaruw JG, Gomez-Jimena MC, Fernandez-Garcia N (2017) Arabinogalactan proteins are involved in salt- adaptation and vesicle trafficking in tabacco by 2 cell-cultures. Front Plant Sci 8: 1092

174. Selvaraj R,Kumar M, Sivaraman D (2015) Arabinogalactan protein a potent immunostimulator. Int J Pharm Phyto Res 7: 732-734

175. D'Adamo P (1996) Larch arabinogalactan. J Naturopath 4: 96-103

176. Dion C, Chappuis E, Ripoll C (2016) Does larch arabinogalactan enhance immune function? A review of mechanistic and clinical trials. Nutr Metab (Lond) 13: 28

177. Sels J, Mathys J, De Coninck BM, Cammue BP, De Bolle MF (2008) Plant pathogenesis-related (PR) proteins: a focus on PR peptides. Plant Physiol Biochem 46: 941-950

178. Liu JJ, Ekramoddoullah AKM (2006) The family 10 of plant pathogenesis-related proteins: their structure, regulation, and function in response to biotic and abiotic stresses. Physiol Mol Plant Pathol 68: 3-13

179. Sreeramanan S, Maziah M, Rosli NM, Sariah M, Xavier R (2006) Enhanced tolerance against a fungal pathogen, Fusarium oxysporum f. sp. cubense (Race 1) in transgenic silk banana. Int J Agri Res 1: 342-354

180. Kovács G, Sági L, Jacon G, Arinaitwe G, Busogoro JP, Thiry E, et al. (2012) Expression of a rice chitinase gene in transgenic banana ('Gros Michel', AAA genome group) confers resistance to black leaf streak disease. Transgenic Res 22: 117-130

181. Ghag SB, Shekhawat UKS, Ganapathi TR (2012) Petunia floral defensins with unique prodomains as novel candidates for development of Fusarium wilt resistance in transgenic banana plants. PLoS One 7(6): e39557

182. Fister AS, Mejia LC, Zhang Y, Herre EA, Maximova SN, Guiltinan MJ (2016) Theobroma cacao L. pathogenesis-related gene tandem array members show diverse expression dynamics in response to pathogen colonization. BMC Genomics 17: 363

183. Van Loon LC, Rep M, Pieterse CM (2006) Significance of inducible defense-related proteins in infected plants. Annu Rev Phytopathol 44: $135-162$
184. Fernandes H, Michalska K, Sikorski M, Jaskolski M (2013) Structural and functional aspects of PR-10 proteins. FEBS J 280: 1169-1199

185. Park CJ, Kim KJ, Shin R, Park JM, Shin YC, Paek KH (2004) Pathogenesis-related protein 10 isolated from hot pepper functions as a ribonuclease in an antiviral pathway. Plant J 37: 186-198

186. Bantignies B, Seguin J, Muzac I, Dédaldéchamp F, Gulick P, Ibrahim R (2000) Direct evidence for ribonucleolytic activity of a PR-10-like protein from white lupin roots. Plant Mol Biol 42: 871-881

187. Koistinen KM, Kokko HI, Hassinen VH, Tervahauta AI, Auriola S, Kärenlampi SO (2002) Stress-related RNase PR-10c is post-translationally modified by glutathione in birch. Plant Cell Environ 25: 707-715

188. Sinha M, Singh RP, Kushwaha GS, Iqbal N, Singh A, Kaushik S, et al. (2014) Current overview of allergens of plant pathogenesis related protein families. Scientific World Journal 2014: 543195

189. Jain S, Kumar A. (2015) The pathogenesis related class 10 proteins in plant defense against biotic and abiotic stresses. Adv Plants Agric Res 2: 305-314

190. Sachetto-Martins G, Franco LO, de Oliveira DE (2000) Plant glycine-rich proteins: a family or just proteins with a common motif? Biochim Biophys Acta 1492: 1-14

191. Mangeon A, Junqueira R. M, Sachetto-Martins G (2010) Functional diversity of the plant glycine-rich proteins superfamily. Plant Signal Behav 5: 99-104

192. Mousavi A, Hotta Y (2005) Glycine-rich proteins: a class of novel proteins. Appl Biochem Biotechnol 120: 169-174

193. Czolpinska M, Rurek M (2018) Plant glycine-rich proteins in stress response: an emerging, still prospective story. Front Plant Sci 9: 302

194. Nawrot R, Tomaszewski L, Czerwoniec A, Goździcka-Józefiak A (2013) Identification of a coding sequence and structure modeling of a glycine-rich RNA-binding protein (CmGRP1) from Chelidonium majus L. Plant Mol Biol Rep 31: 470-476

195. Nawrot R, Kalinowski A, Gozdzicka-Jozefiak A. (2007) Proteomic analysis of Chelidonium majus milky sap using two-dimensional gel electrophoresis and tandem mass spectrometry. Phytochemistry 68: $1612-1622$

196. Zhang X, Zhen JB, Li ZH, Kang, DM, Yang YM, Kong J, et al. (2011) Expression profile of early responsive genes under salt stress in upland cotton (Gossypium hirsutum L.). Plant Mol Biol Rep 29: 626637

197. Huh SU, Paek K-H (2013) Plant RNA binding proteins for control of RNA virus infection. Front Physiol 4: 397

198. Shi WW, Mak ANS, Wong KB, Shaw PC (2016) Structures and ribosomal interaction of ribosome-inactivating proteins. Molecules 21: 1588

199. Musidlak O, Nawrot R, Goździcka-Józefiak A (2017) Which plant proteins are involved in antiviral defense? Review on in vivo and in vitro activities of selected plant proteins against viruses. Int J Mol Sci 18: 2300

200. Schrot J, Weng A, Melzig MF (2015) Ribosome-inactivating and related proteins. Toxins 7: 1556-1615

201. Walsh MJ, Dodd JE, Hautbergue GM (2013) Ribosome-inactivating proteins potent poisons and molecular tools. Virulence 4: 774-784

202. Andricoplo AD, Ceron-Carrasco JP, Mozzarelli A (2018) Bridging molecular docking to molecular dynamics in exploring ligand-protein recognition process: an overiew. Front Pharmacol 9: 438

203. Ganesan S, Faris AV, Comstock AT, Wang Q, Nanua S, Hershenson MB (2012) Quercetin inhibits rhinovirus replication in vitro and in vivo. Antivir Res 94: 258-271 


\section{Antiviral compounds isolated from plants}

\section{Robert Nawrot $^{1 凶}$, Alicja Warowicka², Oskar Musidlak ${ }^{1}$, Martyna Weglewska ${ }^{1}$, Sophia Bałdysz ${ }^{1}$, Anna Goździcka-Józefiak ${ }^{1}$}

1. Molecular Virology Research Unit, Faculty of Biology, Adam Mickiewicz University, Poznań

2. Department of Animal Physiology and Developmental Biology, Faculty of Biology, Adam Mickiewicz University, Poznań

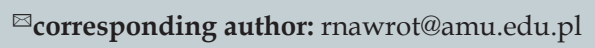

Key words: antiviral compounds from plants, plant immunomodulators

\section{SUMAMRY}

Viruses are intracellular pathogens which utilize a number of host metabolic processes for virus replication in addition to proteins which are encoded for virus itself. Therefore, an effective antiviral drug must interfere with virus encoded proteins without affecting any cellular metabolic processes. Unfortunately, many antiviral drugs that have an inhibitory effect on virus replication, also have an inhibitory effect on molecular processes in infected, as well as uninfected, cells. There is currently no approved remedy for many viruses. Plants represent a large potential source of antiviral agents, such as: alkaloids, flavonoids, phenolic acids, phenylpropanoids, lignins, terpenoids, quinine, tannins, thiophenes, polyacetylenes or proteins. Some of them possess broad spectrum of antiviral activity. 